\title{
A new analytical framework of farming system and agriculture model diversities. A review
}

\author{
Olivier Therond $^{1,2} \cdot$ Michel Duru $^{2} \cdot$ Jean Roger-Estrade $^{3} \cdot$ Guy Richard $^{4}$
}

Accepted: 26 April 2017 /Published online: 6 June 2017

(C) The Author(s) 2017. This article is published with open access at Springerlink.com.

\begin{abstract}
In most current farming system classifications (e.g. "conventional" versus "organic"), each type of farming system encompasses a wide variety of farming practices and performances. Classifying farming systems using concepts such as "ecological", "sustainable intensification" or "agro-ecology" is not satisfactory because the concepts "overlap in... definitions, principles and practices, thus creating...confusion in their meanings, interpretations and implications". Existing classifications most often focus either on biotechnical functioning or on socio-economic contexts of farming systems. We reviewed the literature to develop an original analytical framework of the diversity of farming systems and agriculture models that deal with these limits. To describe this framework, we first present the main differences between three biotechnical types of farming systems differing in the role of ecosystem services and external inputs: chemical input-, biological inputand biodiversity-based farming systems. Second, we describe four key socio-economic contexts which determine development and functioning of these farming systems: globalised commodity-based food systems, circular economies, alternative food systems and integrated landscape approaches. Third, we present our original analytical framework of agriculture models, defined as biotechnical types of farming systems
\end{abstract}

The original version of this article was revised due to a retrospective Open Access order. The erratum is available under DOI 10.1007/s13593-0170451-9.

Olivier Therond

olivier.therond@inra.fr

1 UMR LAE, INRA, Colmar 68021, France

2 UMR AGIR, INRA, Castanet Tolosan 31326, France

3 UMR Agronomie, AgroParisTech, Thiverval-Grignon 78850, France

4 UAR DEPT EA, INRA, 45075 Orleans, France associated with one or a combination of socio-economic contexts differing in the role of relationships based on global market prices and "territorial embeddedness". We demonstrate the potential of this framework by describing six key agriculture models and reviewing key scientific issues in agronomy associated with each one. We then analyse the added value of our analytical framework and its generic character. Lastly, we discuss transversal research issues of the agriculture models, concerning the technologies required, their function in the bioeconomy, their multi-criteria and multilevel assessments, their co-existence and the transitions between them.

Keywords Biodiversity $\cdot$ Ecosystem service $\cdot$ Biological input $\cdot$ Food system $\cdot$ Industrial ecology $\cdot$ Landscape . Embeddedness

\section{Contents}

1. Introduction

2. Farming systems according to the role of ecosystem services and external inputs

2.1 Chemical input-based farming systems

2.2 Biological input-based farming systems

2.3 Biodiversity-based farming systems

3. Socio-economic contexts which determine farming system functioning

3.1 Globalised commodity-based food systems

3.2 Circular economies

3.3 Alternative food systems

3.4 Integrated landscape approaches

4. Diversity of agriculture models and knowledge gaps in agronomy

4.1 Chemical input-based farming systems in globalised commodity-based food systems 
4.2 Biological input-based farming systems in globalised commodity-based food systems and circular economies

4.3 Biodiversity-based farming systems in globalised commodity-based food systems and territorial socio-economic contexts

\section{Discussion}

5.1 Added value of the analytical framework

5.2 Generic character of the analytical framework and agriculture models

5.3 Technologies and bioeconomy in agriculture models

5.4 Multi-level and multi-criteria assessments of agriculture models

5.5 Co-existence of agriculture models

5.6 Transitions between agriculture models

6. Conclusion

References

\section{Introduction}

Croplands and pastures cover about $38 \%$ of Earth's ice-free land. They are the largest use of land on the planet (Foley et al. 2011). During the first half of the twentieth century, agricultural issues were mainly related to crop sequence diversity and management of soil organic matter and biological processes. In the 1940s and 1950s, a divergent view became dominant: using manufactured fertilisers and pesticides instead of diverse rotations to reach high yields (Drinkwater and Snapp 2007; Goulding et al. 2008; Savary 2014). The "Green Revolution", also called "industrial agriculture", based on this paradigm increased significant productivity of the main agricultural crops (Tilman et al. 2001; Box 1). Sections 1.1. Paradigm increased significant productivity of the main agri- cultural crops (Tilman et al. 2001; Box 1). To some extent, it helped address food security issues while limiting transformation of natural ecosystems into agricultural ones (Green et al. 2005). To some extent, it helped address food security issues while limiting transformation of natural ecosystems into agricultural ones (Green et al. 2005). Availability and use of cheap fossil fuel, manufactured inputs based on fossil fuel, irrigation, mechanisation and genetically improved (or high-yielding) cultivars and animal breeds were the main technologies underpinning this new model of agriculture (Gomiero et al. 2011; Goulding et al. 2008; Pretty 2008; Tilman et al. 2001). Inputs were used to boost yield per hectare, while machinery and infrastructure (e.g. for irrigation) increased the productivity of labour (Arizpe et al. 2011). Over the past few decades, however, this industrialisation and intensification of agriculture were recognised over time to cause significant negative environmental impacts. Main features of industrial agriculture and its negative environmental impacts are detailed in Box 1.
Since the 2000s, environmental impacts of industrial agriculture have been considered so important that Foley et al. (2011) claim that "agriculture is a major force driving the environment beyond the planetary boundaries" as defined by Rockström et al. (2009a, b). Likewise, the "International Assessment of Agricultural Knowledge, Science and Technology for Development" (IAASTD 2009) concluded, "business as usual is not an option". Foley et al. (2005) stated that "modern agricultural land-use practices may be trading short-term increases in food production for long-term losses in ecosystem services, including many that are important to agriculture." As a consequence, the need for farming systems which are sustainable as well as productive, less dependent on fuel- and chemical-based inputs and preserve the environment has been increasingly expressed over the past few decades (IAASTD 2009; MEA 2005).

In the quest for sustainable agriculture, many authors seek to identify and qualify sustainable farming practices or systems using terms such as "biodynamic", "community-based", "ecoagriculture", "ecological", "environmentally sensitive", "extensive", "farm-fresh", "free-range", "low-input", "organic", "permaculture", "precision", "smart", "diversified", "integrated" and "conservation" (e.g. Pretty 2008; Garbach et al. 2016). Intense debate continues over whether farming systems described by some of these terms can be qualified as sustainable (Pretty 2008). Many of the most-used terms encompass a wide diversity of farming systems with a wide diversity of environmental and socio-economic performances. For example, organic agriculture, often considered the opposite of conventional agriculture and a possible model for sustainable agriculture, encompasses a wide range of farming systems with differing degrees of diversification and performance (Reeve et al. 2016; Seufert et al. 2012). The same holds true for conservation agriculture, which can describe farming systems based on one, two or all three of its pillars: minimum tillage, permanent soil cover and diversified rotations (Pittelkow et al. 2015). Some of the terms used to describe farming systems refer more to the nature of the technologies used (e.g. precision agriculture), while others refer to how agricultural activities are combined in space and time or at different organisational levels, e.g. "integrated crop-livestock systems" (Moraine et al. 2016). Furthermore, most of these terms focus on inputs, agricultural practices, productions or impacts on the environment, but they do not explicitly consider how farming systems interact with their socio-economic environment at local or global levels and, consequently, their mutual effects. Other more general terms are used to describe potential forms of transition towards sustainable agriculture, the most used being "ecological intensification", "sustainable intensification" and "agro-ecological intensification". These three concepts, however, "overlap in... definitions, principles and practices, thus creating...confusion in their meanings, interpretations and implications. [...] These blurred boundaries currently contribute to the use of these terms 
Box 1. Main features of industrial agriculture and its negative environmental impacts

\section{Main features of industrial agriculture and its negative environmental impacts}

Nitrogen use and impacts

Since the 1960s, use of mineral nitrogen fertilisers has grown approximately 7-fold, while overall yield has increased only 2.4-fold (Hirel et al. 2011; Tilman et al. 2002; Spiertz 2010). Currently, about $64 \%$ of the reactive nitrogen (which excludes non-reactive $\mathrm{N}_{2}$ gas) linked to human activities is created by the Haber-Bosch process. Approximately $80 \%$ of the Haber-Bosch-based nitrogen is destined for agricultural activities. Only $20 \%$ of the reactive nitrogen linked to human activities comes from cultivation-induced biological nitrogen fixation, mainly in crop, pasture and fodder legumes (Galloway et al. 2008). According Spiertz (2010) soya bean represents 50\% of the worldwide area of crop legumes and contributes approximately to $75 \%$ of the nitrogen fixed by crop legumes. Comparison of increases in overall yields and nitrogen fertiliser use show a drastic global decrease in nutrient use efficiency (Hirel et al. 2011; Tilman et al. 2002). In most intensive agricultural production systems of the OECD, on average, over $50 \%$ of the nitrogen applied to fields is not taken up by plants (Hoang and Allaudin 2011). Analysis of the "nitrogen cascade" shows that nitrogen not used by plants is emitted mostly to rivers and the atmosphere (Galloway et al. 2003, 2004) with potential harmful effects on freshwater and marine ecosystems, climates changes and human health (Beman et al. 2005; Bodirsky et al. 2014; Camarguo et al. 2006; Giles 2005; Umar and Iqbal 2007).

\section{Phosphorus use and impacts}

Roughly the same phenomena for nitrogen holds true for phosphorus (see Smil 2000). Annual use of rock phosphate, a non-renewable resource, to produce fertilisers has increased 6- to 7-fold since 1960, and its current global reserves may be depleted in 50-100 years. About $85 \%$ of global demand for phosphorus is for fertiliser production (Cordell et al. 2009). Tilman (2002) indicates that phosphorus fertilisers have contributed to a 2-fold increase in annual terrestrial mobilisation of phosphorus globally. Rosmarin (2004, in Cordell et al. 2009) estimates that about $25 \%$ of phosphorus mined since 1950 is buried in landfills or has ended up in water bodies, leading to eutrophication problems.

Pesticide use and impacts

Along with the increase in fertiliser use, pesticide production increased roughly more than 3 -fold from 1960 to 2000 (Tilman 2001). Use of pesticides has raised strong concerns about their potential negative consequences on biodiversity (Geiger et al. 2010; Gibbons et al. 2014), including stream invertebrates (Beketov et al. 2013), as well as on human health (Nicolopoulou-Stamati et al. 2016; Wilson and Tisdell 2001). The overall cost of pesticides, i.e. regulatory, human-health, environmental, and defensive expenditures, is increasingly considered, raising questions about their cost-benefit ratios (Bourguet and Guillemaud 2016). Intensive use of pesticides also increasingly raises problems of pest resistance (e.g. for weeds Kraehmer et al. 2014; Powles and Yu 2010), which has become more difficult to control (Powles and Yu 2010). Pesticides also can have substantial negative impacts on biological regulation (ecosystem) services (e.g. Emmerson et al. 2016; Geiger et al. 2010).

Irrigation and water scarcity

Due to the 2 -fold increase in irrigated cropland in the past 50 years, $70 \%$ of global freshwater withdrawals and $80-90 \%$ of freshwater consumption are devoted to irrigation. In many irrigated regions, they strongly increased water scarcity and compound salinization issues (Foley et al. 2011; Gomiero et al. 2011).

Tillage, bare soil and soil degradation

Due to high tillage intensity and the increase in bare soil in simplified rotations, soil erosion has strongly increased over the past 50 years, decreasing soil fertility greatly. About $40 \%$ of cropland worldwide may be experiencing some degree of soil erosion, reduced fertility, or overgrazing (Gomiero et al. 2011).

Use of fossil energy and climate impacts

Due to its intensive use of external fuel-based inputs and direct consumption of fuel, industrial agriculture depends greatly on fossil energy, a source of greenhouse gas emissions (Arizpe et al. 2011; Smith et al. 2008; West and Marland 2002). Agriculture represents 52\% and $84 \%$ of global anthropogenic methane and nitrous oxide emissions, respectively, while the net flux of carbon dioxide from agricultural soils seems small (Smith et al. 2008).

Farming system specialisation, landscape simplification and biodiversity degradation

Mechanisation and intensive pesticide use allowed farmers to simplify crop rotations drastically and develop short rotations or monocultures that often caused yield to decline or stagnate (Bennett et al. 2012). In certain regions, development of these specialised cropping systems greatly simplified spatial crop patterns. This was often accompanied by an increase in field size and the removal of or decrease in areas of remnant non-crop habitats (Bianchi et al. 2006; Stoate et al. 2001). This landscape simplification has strong impacts on regulation ecosystem services such as biological regulation services (Bianchi et al. 2006; Rusch et al. 2016; Tscharntke et al. 2005) and regulation of liquid and mass flows (Verhagen et al. 2016), as well as on the biodiversity influenced by landscape heterogeneity (Benton et al. 2003; Gàmez-Virués et al. 2015; Tscharntke et al. 2005). 
for justifying many different kinds of practices and interventions" (Wezel et al. 2015).

To clarify this debate, social-science research distinguishes opposing paradigms representing distinct pathways towards sustainable agriculture: "shallow versus deep sustainability" (Hill 1998), "weak versus strong multi-functionality" (Wilson 2008), "weak versus strong ecological modernisation of agriculture" (Horlings and Marsden 2011) and "life sciences versus agroecological vision" (Levidow et al. 2012). Elaborating on these classifications from an agronomic perspective, Duru et al. (2015a, b) describe two main pathways for ecological modernisation of agriculture by considering the role of ecosystem services.

The first modernisation pathway addresses environmental issues by increasing efficiency of external input use (e.g. fertilisers, pesticides, water), recycling wastes or by-products of one sub-system inside another (Kuisma et al. 2012) and applying best management practices (Ingram 2008) or precision-agriculture technologies (Rains et al. 2011). One key variant of this pathway is based on replacing most or all chemical inputs with biological inputs (Singh et al. 2011) or genetically modified organisms (Godfray et al. 2010). In accordance with the Hill (1998) classification, Duru et al. (2015a, b) call both pathways "efficiency/substitution-based agriculture", using the term "agriculture" to refer to these two types of farming systems. Further in the text, we refer to these two types of farming systems as "input-based farming systems", distinguishing when necessary "chemical input-based" systems, which implement an efficiency-based pathway, from "biological input-based" farming systems, which implement a substitution-based pathway (see Sect. 2).

The second main pathway aims to strongly enhance the ecosystem services provided by biodiversity to agriculture (Zhang et al. 2007). These ecosystem services depend on the level and management of biodiversity at field, farm and landscape levels (Duru et al. 2015a; Kremen et al. 2012). This approach, called "biodiversity-based" by Duru et al. (2015a, b), seeks to develop diversified cropping and farming systems or even landscapes to enhance ecosystem services for both farmers and society and to drastically reduce the dependence on external inputs. This introduces a paradigm shift in the objectives and expected performances of farming systems (Caron et al. 2014; Levidow et al. 2012). Importantly, external inputs and technologies to increase their efficiency can also be used in biodiversity-based farming systems. Developing biodiversity-based farming systems requires extensive redesign of farming systems (Hill 1998).

In a recent review, Duru et al. (2015b) highlighted that developing biodiversity-based farming systems requires changing both natural-resource management strategies and agricultural supply chains (see also Meynard et al. 2016; Fig. 1). However, it remains unclear which types of socioeconomic contexts can favour their development. More generally, to our knowledge, there is a lack of analytical framework to describe relationships between the diversity of biotechnical functioning of farming systems and that of their socio-economic contexts.

Based on a literature review, the first objective of this article is to elaborate on the above classifications to develop an analytical framework of models (or forms) of agriculture that address the characteristics of and interactions between the biotechnical functioning of farming systems and the socio-economic contexts in which they are embedded. The second objective is to use this framework to identify key models of agriculture and their associated and transversal research issues in agronomy. The framework was developed and used to analyse agriculture models that address environmental issues of industrial agriculture in regions where this agriculture model developed, such as intensive agricultural zones in OECD countries.

The framework is progressively presented in the three following sections of the article. In the second section, we present the main biotechnical differences between chemical input-, biological input- and biodiversity-based farming systems, considering the role of ecosystem services and external inputs in the agricultural production process. In the third section, we describe key socio-economic contexts which determine development and functioning of these farming systems: globalised commodity-based food systems and three types of territorial contexts, i.e. circular economies, alternative food systems and integrated landscape approaches. In the fourth section, we present our original analytical framework of agriculture models, defined as biotechnical farming systems embedded in socioeconomic contexts differing in the role of relationships based on global market prices and "territorial embeddedness". We demonstrate the potential of this framework by describing six key agriculture models, identified because they are the main existing and studied models and raise major agronomic issues. When describing agriculture models, we also review key scientific issues in agronomy associated with each one. We then discuss the added value of our analytical framework and the agriculture models identified and their generic character. Lastly, we discuss transversal research issues of the agriculture models concerning the technologies required, their function in the bioeconomy, their multi-criteria and multi-level assessments, their co-existence and the transitions between them.

\section{Farming systems according to the role of ecosystem services and external inputs}

During the Green Revolution, farmers sought to develop the most suitable conditions for crop and animal growth. Thus, they used high-producing cultivars and breeds to increase "growth-defining" factors (production potential in a given climate) and implemented agricultural practices to control abiotic growth-limiting factors (water and nutrients) and biotic 
growth-reducing factors, i.e. pathogens, animal pests and weeds (Ittersum and Rabbinge 1997). In addition, they endeavoured to improve physical and chemical components of soil quality (with drainage, liming or tillage) to ensure the best conditions for root growth and functioning and, consequently, input-use efficiency. In some cases, local climate conditions (e.g. hedges to regulate wind and evapotranspiration) were also improved.

After Costanza et al. (1997) and Daily (1997), the Millennium Ecosystem Assessment (2005) highlighted that human welfare depends strongly on ecosystem goods and services. Zhang et al. (2007) highlighted that agriculture both provides and benefits from ecosystem services. Bommarco et al. (2013) and Duru et al. (2015a) clarified the status of ecosystem services in agricultural production, highlighting that regulation services influencing soil fertility (soil structure and nutrient cycling), water storage and pest control are the key services provided by ecosystems to farmers. Duru et al. (2015a) clearly explained that developing ecosystem services provided to farmers is one way to deal with growth-defining, growth-limiting and growthreducing factors and thus to reduce use of external inputs. As such, following Le Roux et al. (2008), they call them "input ecosystem services". The portion of agricultural production which depends on input ecosystem services (versus external inputs) is a function of the paradigm on which farming systems are based: inputbased or biodiversity-based (Fig. 2; see introduction; Duru et al. 2015a). It is important to keep in mind that even input-based farming systems depend on ecosystem services and that biodiversity-based farming systems can use external inputs (Bommarco et al. 2013; Duru et al. 2015a; Fig. 2). According to the analyses of Duru et al. (2015a, b) and Duru and Therond (2014), and in agreement with the analysis of Gliessman (2007, p. 278), we distinguish the three main biotechnical types of farming systems (Fig. 2).

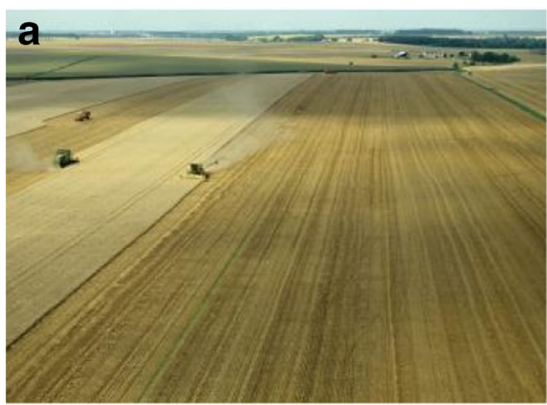

Fig. 1 Landscapes corresponding to different agriculture models (Sect. 4). a A simplified landscape shaped by input-based farming systems (Sect. 2.1) most often encompassed in globalised commodity-based food systems (Sect. 3.1). b A diversified landscape, including non-crop

\subsection{Chemical input-based farming systems}

Farming systems of industrial agriculture are based on strongly simplified crop sequences, standardised crop management and systematic use of chemical inputs: Haber-Bosch-based nitrogen and pesticides. They also rely on potassium and phosphorus fertilisers and, in irrigated areas, on water withdrawals (Box 1). To avoid the risk of limited or reduced yields, farmers often apply more fertilisers and pesticides than needed due to their relatively low prices (Caron et al. 2014; Cordell et al. 2011; Struik et al. 2014). To address current economic constraints and environmental regulations, these chemical input-based farming systems currently seek to optimise inputs according to spatiotemporal plant/animal requirements and to limit pollution (Fig. 2). In other words, to deal with sustainability issues and regulations, farmers managing chemical input-based farming systems follow an efficiency-based modernisation pathway (Hill 1998; Introduction). Most often, it corresponds to incremental adaptations of farming systems (Park et al. 2012). One challenge is to accurately assess the levels of input ecosystem services in time and space to optimise the amounts of additional external inputs required to reach desired production levels. Precision-agriculture technologies based on sensors in the soil or on the crop, machinery, drones, planes and satellites allow monitoring of the dynamics of multiple variables and optimisation of required inputs. They are well developed to deal with nutrient cycling (especially nitrogen) and weeds (e.g. weeding robots, targeted pesticide applications). In addition, farmers use cultivars and animal breeds which are less sensitive to limiting or reducing factors while exhibiting yields which are as high or higher (defining factors). These technologies may allow farming systems to increase input-use efficiency, reduce environmental impacts and, depending on the technology costs, economic performance. Amortising these technologies may lead farmers to continue to increase the size of their farm to reach suitable economies of scale. Environmental regulations can lead farmers to introduce more substantial changes, such as cover

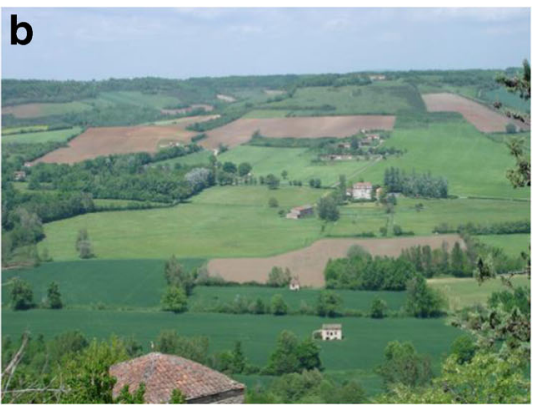

habitats, in which biodiversity-based farming systems aim to develop ecosystem services from field to landscape levels (Sect. 2.3), possibly to feed alternative food systems (Sect. 3.3) 
crops in nitrogen-sensitive areas or landscape features that minimise diffusion of pollutants in aquatic ecosystems. In this case, sowing and destruction dates of cover crops are determined to comply with environmental regulations.

\subsection{Biological input-based farming systems}

Given societal reluctance to chemical pesticides as well as human and ecosystem health issues, some farmers seek to replace all or some chemical inputs with more "environmentally friendly inputs" while still managing a simplified farming system (Fig. 2). As such, to develop biological input-based farming systems, they implement a substitution-based modernisation pathway (Hill 1998, Introduction). Most often, it requires incremental adaptation (pure substitution) or system adaptations such as cropping system adaptations (Park et al. 2012). All technologies (e.g. precision agriculture) used in chemical input-based farming systems can also be used in this type of farming system. Beyond the classic use of organic fertilisers as substitutes for inorganic ones, new biocontrol practices are developed to mimic the ecological functioning of diversified agro-ecosystems while being applied in short rotation- or monoculture-based cropping systems. By using industrially developed natural enemies (e.g. trichogram in maize) and other service-providing organisms (e.g. azotobacters, probiotics, arbuscular mycorrhizal fungi), soil biostimulants and bioinoculants, farmers seek to develop ecological processes underpinning ecosystem services which naturally arise in diversified ecosystems (Lemanceau et al. 2015; Philippot et al. 2013). They can also use biopesticides to avoid eco-toxicity of chemical pesticides. These technologies might enable development of input ecosystem services in the short, medium or long term.

\subsection{Biodiversity-based farming systems}

In biodiversity-based farming systems, developing input ecosystem services requires increasing species/cultivar/breed diversity (e.g. intercropping, diversified field edges, crop sequences) and soil cover (cover crops) while minimising mechanical and chemical disturbances of beneficial biological processes (Fig. 2) (Duru et al. 2015a). One challenge is to develop and manage planned biodiversity from fields to field borders (e.g. edges, flower strips) up to the farmland area to increase ecosystem services. Regarding biological regulations, two main complementary strategies can be distinguished: (i) developing direct effects of plant biodiversity on pathogens, animal pests and weeds via, for example, traps, barriers and resource dilution effects and the breaking of pest cycles ("bottom-up" effects) and (ii) developing effects of planned biodiversity and non-crop habitats on naturally occurring associated biodiversity, which provides biological control of weeds and animal pests ("top-down" effects of natural enemies) (Altieri 1999; Fahrig et al. 2011; Letourneau et al. 2011; Ratnadass et al. 2012; Tscharntke et al. 2005, 2012).
Fig. 2 Key features of three biotechnical types of farming systems according to the portion of agricultural production derived from ecosystem services and external anthropogenic inputs

\begin{tabular}{|c|c|c|c|}
\hline & & Main objectives & $\begin{array}{l}\text { Main features of farming } \\
\text { systems and practices }\end{array}$ \\
\hline \multirow[t]{2}{*}{ 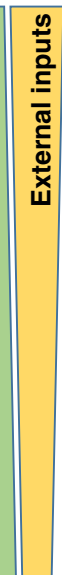 } & $\begin{array}{l}\text { Chemical } \\
\text { input-based } \\
\text { farming } \\
\text { system }\end{array}$ & $\begin{array}{l}\text {-Increase input efficiency } \\
\text { and decrease pollutions } \\
\text {-Often associated with } \\
\text { "sustainable intensification" }\end{array}$ & $\begin{array}{l}\text {-Specialised farms with } \\
\text { standardised practices in } \\
\text { simplified crop sequences (few } \\
\text { crops or monoculture) based on } \\
\text { external chemical inputs } \\
\text {-Landscape features imposed by } \\
\text { environmental regulations }\end{array}$ \\
\hline & $\begin{array}{l}\text { Biological } \\
\text { input-based } \\
\text { farming } \\
\text { system }\end{array}$ & $\begin{array}{l}\text {-Decrease impacts on } \\
\text { biodiversity and human } \\
\text { health by replacing some or } \\
\text { all chemical inputs with } \\
\text { biological inputs }\end{array}$ & $\begin{array}{l}\text {-Specialised farms with } \\
\text { standardised practices in } \\
\text { simplified crop sequences (few } \\
\text { crops or monoculture) based on } \\
\text { external biological inputs } \\
\text {-Landscape features imposed by } \\
\text { regulations } \\
\text {-Possible integration with } \\
\text { livestock }\end{array}$ \\
\hline 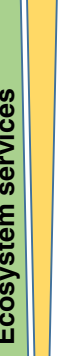 & $\begin{array}{l}\text { Biodiversity- } \\
\text { based } \\
\text { farming } \\
\text { system }\end{array}$ & $\begin{array}{l}\text {-Development and } \\
\text { management of biodiversity } \\
\text { to increase ecosystem } \\
\text { services and decrease } \\
\text { external inputs } \\
\text {-Often associated with } \\
\text { "(agro)ecological } \\
\text { intensification" }\end{array}$ & $\begin{array}{l}\text {-Diversified farms with site- } \\
\text { dependent agro-ecological } \\
\text { practices in diversified crop } \\
\text { sequences } \\
\text {-Non-crop habitats to increase } \\
\text { ecosystem services (in } \\
\text { compliance with regulations) } \\
\text {-Possible deep integration with } \\
\text { livestock in "integrated crop- } \\
\text { livestock systems" }\end{array}$ \\
\hline
\end{tabular}


When biodiversity-based farming systems use chemical or biological inputs to increase production beyond the level allowed by input ecosystem services alone, they must use them sparingly to avoid reducing expected short- and longterm benefits of the input ecosystem services (Duru et al. 2015a; Pisante et al. 2015). As shown by Biggs R et al. (2012), to increase the level and resilience of ecosystem services, these farming systems must manage three key properties of agricultural ecosystems: diversity-redundancy, connectivity and slow variables. While management of the first is commonly identified in the literature on agro-ecosystems, management of the latter two is mentioned less often. Connectivity among biophysical entities determines circulation of matter (including organisms) and energy and thus the system's performance. It influences the abilities of species to disperse to other habitats and/or complete their life cycles (Tscharntke et al. 2005). The state of slow variables (e.g. soil organic matter, trophic networks) influences dynamics of associated fast variables (e.g. nutrient and water cycling, biological regulations). Short-, middle- and long-term management of slow variables determines daily (e.g. soil nitrogen and phosphorus availability, biological regulation), yearly (e.g. soil structure) and, by nature, long-term system functioning (e.g. soil organic matter and trophic network dynamics). By managing these three properties over multiple scales, farmers may greatly increase ecosystem integrity, i.e. its selforganising capacity (Müller et al. 2000).

Most often, developing a biodiversity-based farming system requires transformational changes (Park et al. 2012). It is important to keep in mind that using living biological inputs or biostimulants in biological inputbased farming systems can be a step towards developing biodiversity-based farming systems: farmers begin developing production systems based on biodiversity, even if biological inputs are industrially manufactured and imported into the agricultural ecosystem (e.g. industrially developed natural enemies).

In biodiversity-based farming systems, agricultural practices (including species and cultivar choices) to provide high levels of input ecosystem services are sitedependent (Caron et al. 2014; Duru et al. 2015a; Giller et al. 2015; Lyon et al. 2011; Tittonell et al. 2012). Thus, agricultural practices are considered as "situated action" (Crane et al. 2011). Managing uncertainties in effects of agricultural practices on ecological processes and, in turn, on ecosystem services, requires implementing an adaptive management strategy. This corresponds to experiential learning about system functioning based on iterative cycles to design and implement actions and to monitor and assess their effects (Duru et al. 2015a). Local networking among farmers allows for social learning of management strategies, which helps farmers to cope with these uncertainties (Moore 2011).

\section{Socio-economic contexts which determine farming system functioning}

Farming systems are parts of food systems, which consist of many institutions, technologies and practices to produce, process, package, distribute, sell and consume food. The first four of these activities constitute the "food supply chain" or "agrofood supply chain". The food system encompasses the upstream portion of the production process, which includes the supplying of inputs to farming systems. According to Capone et al. (2014), "food systems influence not only what is being consumed and how it is produced and acquired, but also who is able to eat and how nutritious their food is". Food systems encompass interactions between activities related to food and non-food agricultural commodities. Institutions and practices for managing natural resources (e.g. water, soil, biodiversity) used in agriculture, i.e. the social sub-system and dynamics of socio-ecological systems, strongly interact with farming and food systems (Duru et al. 2015b; Foran et al. 2014).

Dominant food systems are based on complex, industrial and globalised food supply chains of generic standardised products in which relationships and competition are centred on global market prices (Fig. 3). Their main characteristics are described in Sect. 3.1. Conceptualised in opposition to these "conventional food systems", "alternative food systems" are developed at the local, regional or even global levels (Murdoch et al. 2000) (Fig. 3; Sect. 3.3). One classic way to distinguish these different food systems clearly is to estimate their embeddedness, i.e. the degree to which social dimensions mitigate purely economic relationships and behaviours (Murdoch et al. 2000; Penker 2006; Sonnino and Marsden 2006). Penker (2006) identified three key dimensions of embeddedness of economic activities within food systems: (i) the social context, i.e. the nature of relationships between people in the food network (e.g. trust, transparency, fair trade); (ii) the spatial background associated with agricultural products, i.e. representation of the regions where food originates; and (iii) the nature background associated with products, i.e. food production processes, including agricultural practices and their impacts on the environment and health. This allows describing the territorial embeddedness of food systems (Sonnino and Marsden 2006; Fig. 3).

By definition, food systems determine opportunities for possible inputs to farming systems, markets for farming system production and, in turn, their biotechnical functioning. Other key socio-economic contexts can determine the inputs, agricultural practices and productions of farming systems (Fig. 3). Farming systems can be involved in circular economies that seek to locally or regionally close loops of matter and energy and in turn decrease natural resource use, waste and pollution (Ghisellini et al. 2014). They can also be involved in rural development projects based on an integrated landscape approach (Freeman et al. 2015). Concerning 
agriculture, these development projects can meet sustainability objectives through the development of synergies between circular economies, alternative food systems and collective landscape management. The main characteristics of circular economies and integrated landscape approaches are respectively presented in Sects. 3.2 and 3.4 and outlined in Fig. 3. As explained hereafter, circular economies, alternative food systems and integrated landscape approaches are three different and potentially complementary types of socio-economic contexts which can increase territorial embeddedness of agriculture's economic activities relative to those in globalised commodity-based food systems, which are strongly determined by global market prices (Fig. 3).

\subsection{Globalised commodity-based food systems}

Development of industrial agriculture in OECD countries is based on increasing productivity and efficiency via industrial processes and standardised techniques throughout the entire food system. It has pushed farmers to produce as much as possible for the lowest cost and has prompted the specialisation of farming systems and regions according their comparative advantages (Lyson and Guptill 2004; Murdoch et al. 2000; O'Kane 2012). It is underpinned by techno-scientific knowledge about the industrial and standardised procedures and techniques involved in production, processing and distribution (Levidow et al. 2012; Lyson and Guptill 2004; Murdoch et al. 2000). In this type of food system, industrial processing is used to produce large amounts of food which are inexpensive, convenient, safe and attractive. More generally, these food systems "circumvent" or "outflank" nature in the food sector by replacing natural processes or products with industrial processes that obscure the origins of food (Murdoch et al. 2000), producing "food from nowhere" (Campbell 2009). This has resulted in the strong development of trading generic and standardised commodities (Murdoch et al. 2000).

The use of widely distributed standardised technology and techniques to produce generic products with no specific quality characteristics causes competition to become centred on prices. Accordingly, social relationships are strongly influenced by economic and commodity relations, i.e. "disembedded" (Murdoch et al. 2000; Penker 2006). However, several authors (e.g. Murdoch et al. 2000; Sonnino and Marsden 2006) claim that globalised food systems are not as territorially disembedded as they seem, as they are rooted in social and ecological regional contexts in which agricultural production occurs (Fig. 3).

These commodity-based food systems encompass markets for industrial inputs (e.g. fertilisers, pesticides), animal feeds (e.g. soya bean meal), raw/bulk agricultural commodities (e.g. wheat) and minimally processed foods (e.g. durum wheat semolina). They are increasingly based on markets of fractionated raw products as standardised and often interchangeable components (e.g. sugars, oils) and ultraprocessed food based on these components (Khoury et al. 2014; Levidow et al. 2014; Marsden 2012; Monteiro et al. 2013; Tilman et al. 2002).

Commodity-based food systems have actively globalised in recent decades. This globalisation has concentrated power in large companies and retailers which manage complex and long-distance industrial supply chains in and between which relationships and competition are centred on prices in globalised commodity markets. In these globalised commodity-based food systems, farmers receive an everdecreasing share of the total added value and often have an ever-decreasing decisional autonomy about what and how to produce (O'Kane 2012; Marsden 2011; Murdoch et al. 2000; Simoncini 2015).

The rapid development of globalised food systems in recent decades had a strong influence on the homogenisation of national food systems (Khoury et al. 2014) and on human health (e.g. Monteiro et al. 2013; O'Kane 2012). The globalisation of food systems does not preclude organising agricultural markets at regional levels. They develop when regional commodities are competitive in the global market (e.g. sunflower or rapeseed meal versus soya bean meal).

Commoditisation and globalisation of food systems also have strong negative environmental impacts (O'Kane 2012). The main environmental impacts of industrialisation and specialisation of farming systems and regions are presented in Box 1. It is important to note that negative environmental impacts of globalised commodity-based food systems depend not only on farming practices but also on consequences of long-distance trading. For example, from 1961 to 2010, the amount of "nitrogen-containing products" traded between countries increased nearly 8 -fold and now represents one third of the nitrogen embedded in the total global agricultural production. Most are included in animal feed, with soya bean products representing the largest portion (44\%), provided by a few countries, mainly the USA, Argentina and Brazil (Lassaletta et al. 2014). Concentration of nitrogen flows due to imports into certain production regions (e.g. livestock-oriented) induce a cascade of transfers and transformations that often severely contaminate the air, water and soil in these regions (Billen et al. 2013, 2014a, b, 2015; Bodirsky et al. 2012; Galloway et al. 2003, 2008). In contrast, food systems which depend less on large-scale trade generally emit less nitrogen into the environment (Billen et al. 2015).

\subsection{Circular economies}

Regional, national (e.g. China, France, UK) and supranational (e.g. European Union) policies promote development of circular economies to increase economic and environmental performances of economic activities, including agriculture. 
Fig. 3 Main features of key nonexclusive socio-economic contexts that determine the biotechnical functioning of farming systems. Territorial embeddedness, i.e. social, spatial and ecological issues which mitigate purely economic relationships and behaviours centred on global market prices, is assumed to increase from top to bottom. Because each socioeconomic context can take many forms with different types of territorial embeddedness, the relative position of each is illustrative and does not follow a strict order (see Fig. 4). The local level is the level at which individual or groups of municipalities or administrative districts implement rural development projects. The regional level lies between local and global levels and usually corresponds to areas within countries or across neighbouring countries

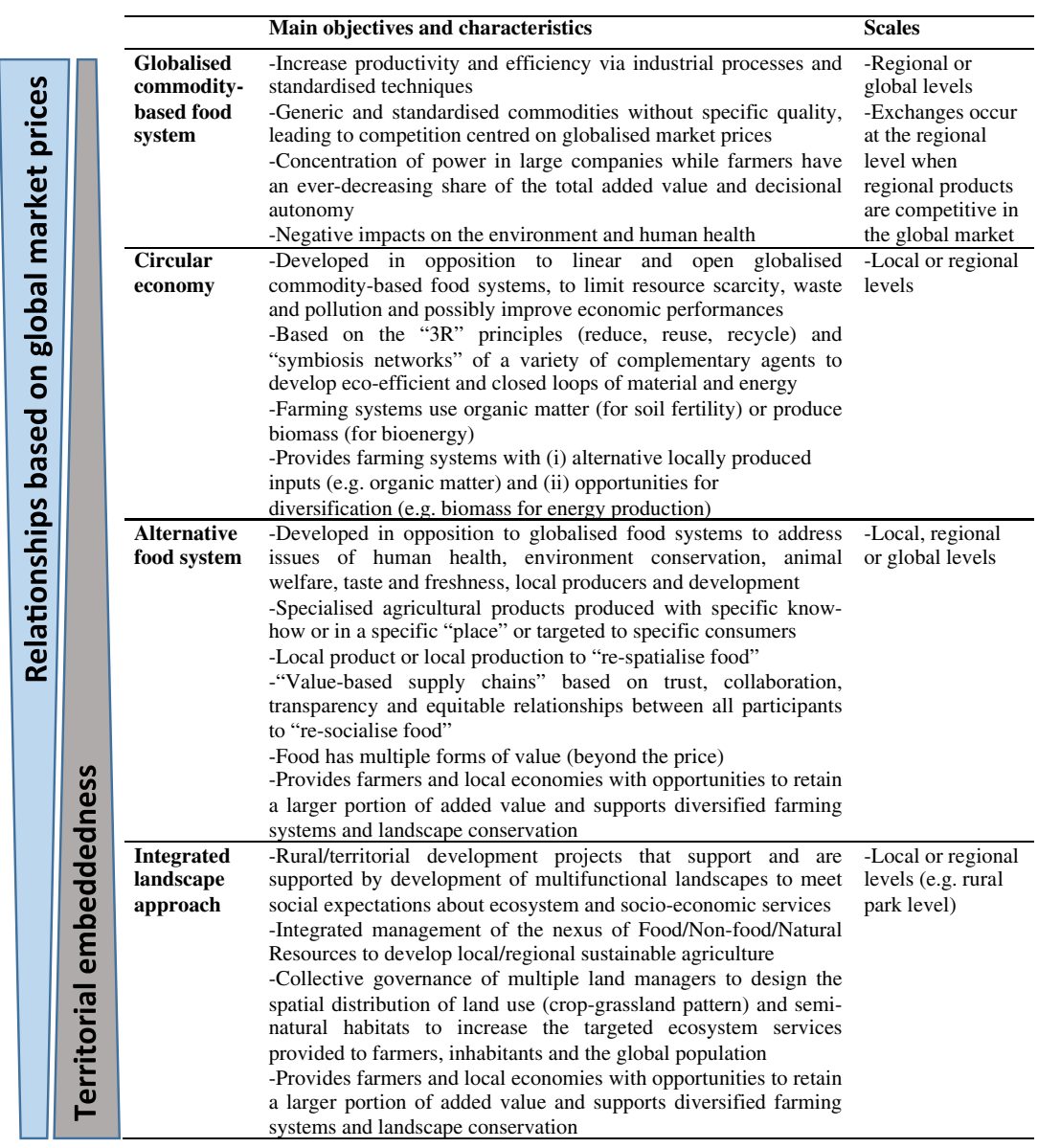

Circular economy is rooted in ecological and environmental economics and industrial ecology. Circular economies developed in opposition to linear and open management of material and energy flows in industrial supply chains, in which downstream pollution and waste emissions are spatially separated from upstream production systems, such as in globalised commodity-based food systems (see previous section). Based on the "3R" principles - Reduce, Reuse, Recyclecircular economies develop eco-efficient and closed loops of material and energy at the company, local or regional levels to strongly decrease resource scarcities, waste and pollution and, possibly, to improve economic performances (Ghisellini et al. 2014; Lieder and Rashid 2016). In other words, the challenge is to transform linear economies organised like a river into circular economies that function like a lake (Stahel 2016). Regarding the production sector at the local or regional level, circular economies aim to develop "symbiosis networks" of a variety of complementary agents in which outputs or "wastes" of one agent are used, directly or indirectly, as inputs by another. Performances of circular economies are assessed using a life cycle perspective of the entire agent network. Circular economies are developed via top-down and "command and control" approaches (e.g. China) or bottom-up approaches based on local agent initiatives (e.g. environmental organisations in Europe). Developing circular economies may require redesigning production systems, infrastructure, cultural frameworks or social systems (Ghisellini et al. 2014).

Regarding agriculture, this form of territorial integration of economic activities may provide farming systems with (i) alternative locally produced inputs such as organic matter and nutrients derived from wastes to increase soil organic matter content and associated ecosystem services and (ii) opportunities to market biomass for energy production at local or regional levels (dedicated crops or residues such as straw). By creating new markets, mainly for bioenergy, circular economies provide farming systems with key opportunities to diversify (Kline et al. 2016) and reduce greenhouse gas emissions (Ghisellini et al. 2014).

Development of trading between specialised crop and livestock farms (e.g. especially organic fertilisers such as manure, straw or even animal feed) is a model of circular economy limited to agriculture. Developing exchanges between specialised farms can provide opportunities to diversify (e.g. introducing lucerne, grain legumes, or grasslands in cropping systems). Exchanges between crop and livestock systems may increase soil organic matter through manure application or enhance biological regulations through spatiotemporal crop diversification. Logistical (transport and processing) and 
economic issues (market stability) can be managed directly by farmers or other economic agents, such as agricultural cooperatives (Martin et al. 2016; Moraine et al. 2016). Trading can also be developed between farming systems and other operators of the food supply chain (e.g. food processing, transporting) or other sectors of activity (e.g. production of organic "waste") (Nitschelm et al. 2015).

Developing local or regional circular economies provides farming systems with opportunities to short-circuit globalised supply chains for certain locally managed inputs and products. Local or regional circular economies most often seek to develop ecological and spatial embeddedness.

\subsection{Alternative food systems}

Alternative food systems have actively developed in OECD countries in opposition to globalised commodity-based food systems (Albrecht et al. 2013; Lerman 2012; Lyson and Guptill 2004; Murdoch et al. 2000; Penker 2006; Sonnino and Marsden 2006). They are organised around networks of producers and consumers, possibly with intermediaries. They seek to "re-socialise" or "re-spatialise food" (Marsden et al. 2000), i.e. to develop "food from somewhere" (Campbell 2009). By developing social, spatial and ecological embeddedness, they are assumed to address consumer concerns about human health (e.g. food safety, zoonotic diseases, nutrition), environmental issues, animal welfare, taste and freshness and to support small or local producers, local skills and rural and territorial developments (Lyson and Guptill 2004; Penker 2006; Sonnino and Marsden 2006). Alternative food systems are based on specialised (versus standardised) and dedicated (versus generic) agricultural products. Specialised products are produced with specific knowhow or in a particular "place" so that the quality of the product is an important component of its competitiveness (Murdoch et al. 2000). They provide integral and comprehensive product identity via quality characteristics that consumers recognise (Levidow et al. 2012). According to Renting et al. (2003), "it is not the distance over which the product is transported that is critical, but the fact that it is embedded with value-laden information when it reaches the consumer". However, claiming a particular quality (e.g. origin) does not preclude adopting the industrial and commercial criteria required for economic performances (Lerman 2012; Murdoch et al. 2000). Dedicated products are targeted to specific consumers attached to the values which the products provide (e.g. ecology or equity) (Murdoch et al. 2000).

Alternative food systems can be classified according to the type of food supply chain (e.g. face-to-face, spatial proximity, spatially extended for export) and the degree to which they focus on an ecological or regional identity (Marsden et al. 2000, 2012). Accordingly, they can develop at local and regional levels and through longer value-based supply chains oriented towards export (Marsden et al. 2000, 2012; Murdoch et al. 2000). They can be a component of hybrid supply chains, which incorporate purely economic commodities and non-economic integral product values and goals (Bloom and Hinrichs 2011; Lerman 2012; Murdoch et al. 2000; Sonnino and Marsden 2006).

Alternative food systems are often organised around "value-based supply chains" defined by trust, collaboration, transparency or equitable relationships between all participants, i.e. high social embeddedness (Lerman 2012). They are often considered one of the greatest opportunities for farmers and local economies to retain a larger portion of added value within food systems (Lerman 2012; Sonnino and Marsden 2006). More generally, alternative food systems can provide important rural development opportunities for added value and social networks (Marsden et al. 2000; Marsden 2012).

In alternative food systems, two main non-exclusive strategies can help to develop spatial embeddedness: (i) indicating geographic origins across regional and global markets (localised production) and (ii) developing a "local food system" (local product). The latter was first conceptualised by French scholars in 1996 as "Systèmes Agroalimentaires Localisés". In the former, "local" refers to the location (positionality) of elements in the supply chain, while in the latter, it refers to the fact that food systems are anchored into a given territory, i.e. a space with specific biophysical, social and cultural dimensions (Bowen and Mutersbaugh 2014). Local food systems can "short-circuit" the long industrial supply chains in global food systems (Marsden et al. 2000; Sonnino and Marsden 2006).

Through ecological embeddedness, alternative food systems can provide farmers with opportunities to develop or conserve specific farming systems (e.g. biodiversity-based) instead of adopting standard, recommended or contracted practices associated with industrial supply-chain management (Murdoch et al. 2000; O'Kane 2012). Consequently, alternative food systems are often promoted by organisations responsible for preserving or developing local or regional biodiversity and multi-service landscapes (e.g. rural parks; Pinna 2016; Simoncini 2015).

Although alternative food systems are often idealised, it remains difficult to assess the effectiveness and resilience with which they can meet goals of sustainable agriculture and rural development (Albrecht et al. 2013; Lerman 2012; Sonnino and Marsden 2006). For example, local supply chains may have greater energy consumption and greenhouse gas emissions per unit of product due to the lack of economy of size (Lerman 2012).

\subsection{Integrated landscape approaches}

The landscape level is increasingly considered the most suitable and productive for addressing sustainability issues 
(Freeman et al. 2015; Reed et al. 2016; Sayer et al. 2013; Wu 2013). Studies about "landscape approaches" provide conceptual frameworks, principles and guidelines to implement sustainable projects at local or regional levels (Freeman et al. 2015; Milder et al. 2014; Reed et al. 2016; Sayer et al. 2013).

Sectoral and integrated landscape approaches have been identified as the two main initiatives to address sustainability issues at the landscape level (Freeman et al. 2015). Sectoral landscape approaches address one of few environmental goals, such as water deficit management (e.g. Murgue et al. 2015), territorial crop-livestock integration (e.g. Moraine et al. 2016), hedgerow networks (e.g. Groot et al. 2010), biological regulations (e.g. Gaba et al. 2014; Scherr and McNeely 2008; Steingröver et al. 2010) and biodiversity conservation (e.g. Berthet et al. 2012). They require a landscape design approach (Nassauer and Opdam 2008) based on landscape agronomy, i.e. analysis of interactions among agricultural activities, the landscape matrix and natural resources (Benoît et al. 2012).

Integrated landscape approaches (or initiatives) are framed around the multi-functionality of landscapes to meet multiple socio-economic and environmental objectives. They are based on identification, analysis and explicit management of tradeoffs between objectives via collaborative transdisciplinary approaches integrating generic and local knowledge. They most often use holistic, negotiated and transparent methods to address sustainability issues (Freeman et al. 2015; Milder et al. 2014; Reed et al. 2016). In these approaches, landscapes are often conceptualised as complex adaptive social-ecological systems made up of ecological and social processes in interaction at different levels (Biggs et al. 2012; Duru et al. 2015b; Freeman et al. 2015; Wu 2013).

The objective of integrated landscape approaches is to develop rural/territorial development projects which support and are supported by the development of multifunctional landscapes that meet social expectations about ecosystem and socio-economic services. By nature, these territorial development projects are based on strong territorial embeddedness, and agriculture is one of the key economic sectors involved. They may enable the development of an "eco-economy paradigm which replaces, and indeed relocates, agriculture and its policies into the heart of regional and local systems of ecological, economic and community development" (Marsden 2012, see also Horlings and Marsden 2011). The eco-economies would recapture "value at the local and regional level by creating ecologically based products and services, which then create market and consumption niches" (Marsden 2010).

Developing landscapes that supply multiple ecosystem services requires collective governance of multiple land managers to design the spatial distribution of agricultural land use (crop-grassland pattern) and non-crop habitats, which may increase levels of ecosystem services which depend on landscape composition and configuration (e.g. biological regulations, mass and liquid flow regulations) (Mastrangelo et al. 2014; Wu 2013). One challenge is to develop landscapes which can provide expected ecosystem services to farmers, local inhabitants and the global population (e.g. global climate regulation). Similar to sectoral landscape approaches, this requires landscape design and agronomy approaches. Another challenge of collective multi-service landscape management is to address uncertainties in ecological processes, effects of management practices on the landscape and its processes and the lack of control over individual practices at the landscape level. Adaptive landscape management strategies are required to address these uncertainties. Like management of biodiversity-based farming systems, it is based on iterative cycles of design, implementation, monitoring and assessment (see Sect. 2.3). Specifically, it should be based on conceptualising the landscape as a complex adaptive socialecological system, structured participatory and social learning processes and polycentric sub-systems of governance (Duru et al. 2015b; Biggs et al. 2012).

Agricultural issues in integrated landscape approaches (or territorial development projects) are mainly concerned with food quantity and quality, biomass production for non-food use (bioenergy and industrial use), ecosystem and human health, ecosystem services to farmers and society, natural resource management (including biodiversity conservation) and socio-economic issues (e.g. Freeman et al. 2015, Milder et al. 2014; Reed et al. 2016; Sayer et al. 2013). Food, energy and technological sovereignty are often additional key issues. They can be broadly defined as the right of nations and people to design or control their own food and energy systems and agro-ecological technologies (Altieri et al. 2012; Duru et al. 2015b; Kline et al. 2016; Koohafkan et al. 2012; Marsden and Farioli 2015).

In brief, the challenge for agriculture in integrated landscape approaches is to manage the "nexus of Food/Nonfood/Natural resources" (including ecosystem services) to ensure the development of local/regional sustainable agriculture which contributes to sustainable development as a whole, from local to global levels. Here, developing circular economies is a major way to address the challenge of local or regional bioenergy production (Kline et al. 2016; Marsden and Farioli 2015; Milder et al. 2014). Duru et al. (2015b) outline conceptual and methodological frameworks to help stakeholders design the agro-ecological transition at local or regional levels to manage this nexus. They highlight the need to consider objectives of, limitations of, and interactions among farming systems, supply chains and natural resource management.

Integrated landscape approaches require strong social, spatial and ecological embeddedness. Trust, transparency and equitable relationships among all participants are key social dimensions for the success of these approaches (Freeman et al. 
2015; Reed et al. 2016; Sayer et al. 2013). Landscape projects are spatially embedded because they are deeply anchored to a given territory. Ecological concerns are necessary in the development of agricultural activities which meet local, regional and global sustainability objectives in the medium to long terms (Bacon et al. 2012; Penker 2006; Pinna 2017). More generally, the success of integrated landscape approaches is strongly determined by governance practices (Biggs et al. 2012; Duru et al. 2015b; Kline et al. 2016; Marsden and Farioli 2015; Sayer et al. 2013).

\section{Diversity of agriculture models and knowledge gaps in agronomy}

Considering the three types of farming systems (Sect. 2) and the key characteristics of the main socio-economic contexts in which they can be embedded (Sect. 3), we developed an analytical framework of the diversity of agriculture models (Fig. 4). Each agriculture model corresponds to a type of farming system associated with one or a combination of socio-economic contexts. Therefore, two dimensions characterise each agriculture model: (i) the balance between external inputs versus ecosystem services in the biotechnical functioning of farming systems (vertical axis; Figs. 2 and 4) and (ii) the balance between the relationships farming systems have with their socioeconomic environment, i.e. relationships based on global market prices versus territorial embeddedness (vertical axis in Fig. 3 and horizontal axis in Fig. 4). The composite axes of Fig. 4 explicitly represent both balances which underpin the corresponding dimensions.

Using this framework and given potential and consistent relationships between the three types of farming systems and the four socio-economic contexts characterised in the previous section, we identified six agriculture models which address sustainability issues of the industrial agriculture model in different ways. We identified these key agriculture models because they represent the main existing and studied models and raise major agronomic research issues. This list is not intended to be exhaustive and may be supplemented with future studies (see Sect. 5.2). Some of the agriculture models are well developed and correspond to the main socio-technical regime; others correspond to niches or are potential forms of agriculture within a given region or OECD country (Duru et al. 2015b). In most territories, different agriculture models co-exist (see Sect. 5.5).

Hereafter, we first present agriculture models involving chemical and biological input-based farming systems and then those involving biodiversity-based systems. For each, we identify key research issues in agronomy.
4.1 Chemical input-based farming systems in globalised commodity-based food systems

The first agriculture model identified corresponds to chemical input-based farming systems (specialised cash-crop and livestock farms) embedded in globalised commodity-based food systems (lower left quadrant of Fig. 4). This is the dominant agriculture model in Western Europe and USA (Levidow et al. 2014; Lyson and Guptill 2004). Economic resilience of these farming systems to price variability and biophysical hazards can be supported respectively by contracts and insurance schemes, both provided by globalised commodity-based food supply chains. These insurance instruments may lead farmers to plant riskier cash crops more often, resulting in relatively more monocultures (Müller and Kreuer 2016). In this agriculture model, large companies and retailers often retain most of the added value (Sect. 3.1). Because they are integrated in dynamics of large-scale commodity-based food systems, these farming systems are often poorly connected to local natural resource management issues and strategies, leading to conflicts over issues such as water shortages due to irrigation, water quality due to pollution and erosion due to bare soils. A typical example of this decoupling is the world soya bean market, which grew strongly during the 1990s and led to high environmental impacts in regions where soya bean is grown (e.g. pesticide pollution, deforestation) as well in those where it is used as feed for specialised and concentrated livestock enterprises (i.e. nitrogen emissions) (Billen et al. 2014a, b, Sect. 3.1).

To increase (weak) sustainability of this agriculture model, much research currently focuses on two main strategies. The first seeks to develop smart agricultural technologies (e.g. genetic engineering, precision farming, new fertilisers and pesticides) to increase input-use efficiency. Breeding highproducing cultivars and breeds less sensitive to limiting and reducing factors is a continual research issue. Developing best management practices to apply the "Right Product, Right Rate, Right Time, and Right Place" remains a challenge (Spiertz 2012). It seems that there is still much room to improve efficiency of (i) nitrogen and phosphorus fertiliser use (Goulding et al. 2008; Cordell et al. 2011), including use of "enhanced-efficiency fertilisers" such as controlled-release fertilisers and nitrification/urease inhibitors (Timilsena et al. 2015), (ii) water use (Ali and Talukder 2008; Playan and Mateos 2006) and (iii) pesticide use (e.g. Gaba et al. 2016; Hossard et al. 2016; Lechenet et al. 2017). Research is still needed to estimate the room for improving these efficiencies, to assess potential impacts on agricultural and environmental performances from field to landscape/catchment levels in different production situations and to develop the knowledge required to implement best management practices. The second strategy seeks to develop knowledge about landscape features which can minimise diffusion of pollutants in aquatic 
ecosystems (e.g. grassed and riparian buffer strips/zones, Anbumozhi et al. 2005; Borin et al. 2010; Correll 2005). Developing user-friendly decision-support systems which integrate up-to-date scientific knowledge remains a challenge for research seeking to support this agriculture model.

\subsection{Biological input-based farming systems in globalised commodity-based food systems and circular economies}

Biological input-based farming systems usually are also embedded in and mainly interact with globalised commoditybased food supply chains for the supply of biological inputs (e.g. biostimulants, biopesticides, external organisms) and trading of their products. However, they may evolve due to additional opportunities provided by circular economies to replace chemical inputs with biological inputs and for diversification (e.g. biomass production for bioenergy). These two degrees of integration in globalised commodity-based food systems helped us to distinguish two agriculture models (lower left and right quadrants in Fig. 4). When biological input-based farming systems are involved in circular economies, they are more embedded in territorial socio-economic dynamics (Sect. 3.2).

Biological input-based farming systems are strongly promoted by both the European Union and policies of its Member States (Levidow et al. 2014). In both models, however, use of living biological inputs for biological control remains in its infancy. While their effects are well known, and their efficacy has been demonstrated by research on some iconic living inputs (e.g. inoculation of Rhizobia in leguminous cropping systems; Lemanceau et al. 2015), the actual effects of many biological inputs such as biostimulants have not been soundly demonstrated at the field level (Reeve et al. 2016). Moreover, they generally have low resilience, leading farmers to apply

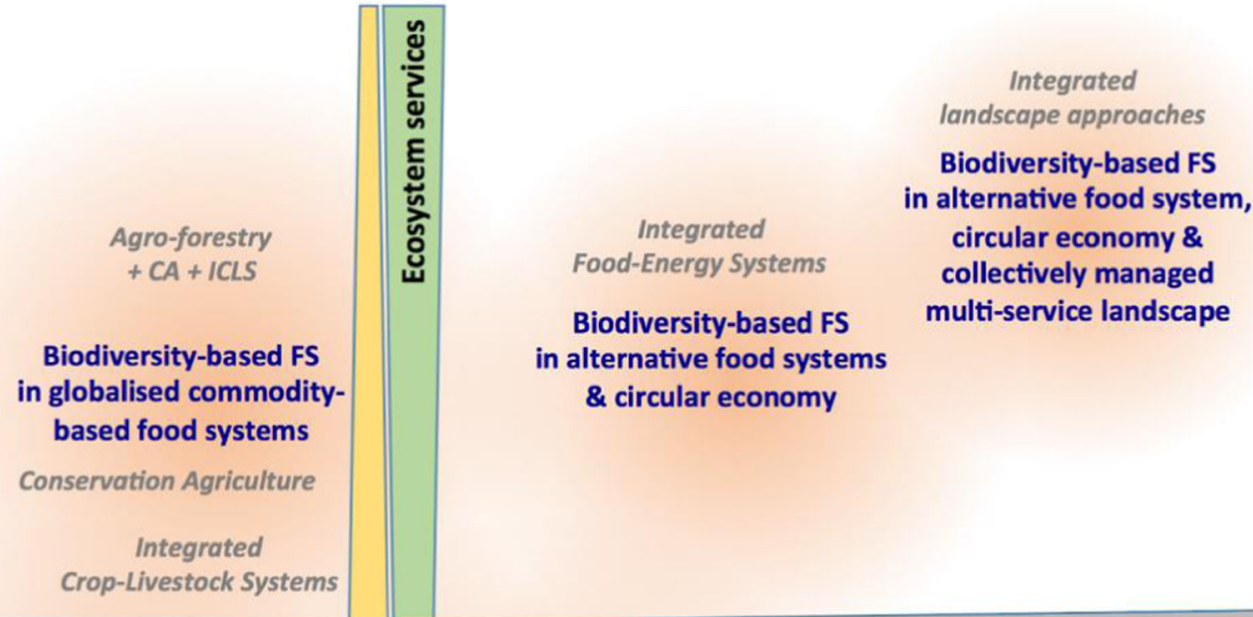

Territorial embeddedness

\section{Relationships based on global market prices}

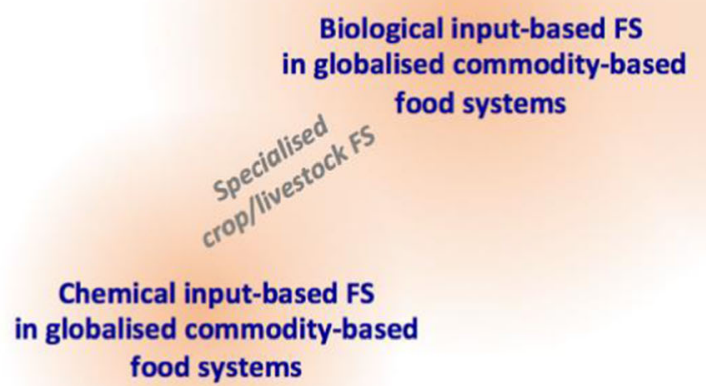

Fig. 4 Six key models of agriculture (blue text) according to the degree to which biotechnical functioning of farming systems (FS) is based on ecosystem services versus external inputs ( $Y$-axis) and the degree to which their relationships with socio-economic contexts

\section{Biological input-based FS \\ in circular economy \\ Exchanges between \\ crop \& livestock FS}

are based on global market prices versus territorial embeddedness ( $X$-axis). Iconic examples are presented in grey. $C A$ conservation agriculture, ICLS Integrated Crop Livestock System 
them regularly (e.g. annually). One reason may be that these products are used in the same way as chemical products, although "being biological these products have to be applied in accordance with their ecological requirements" (Alabouvette et al. 2006). Furthermore, it is still necessary "to carefully study the effect of inoculum type, application rate and time of application to ensure efficacy of biological control" (ibid). In other words, best management practices remain to be defined. For example, efficacy of biopesticides (Cordeau et al. 2016), alone or in combination with chemical pesticides, possible development of resistance like that developed to chemical pesticides (Siegwart et al. 2015) and effective application technologies and practices (Gan-Mor and Matthews 2003) require sound multi-disciplinary scientific research (Hynes and Boyetchko 2006; Glare et al. 2012).

Research on dynamics of nutrient availability is also needed to manage organic fertilisation effectively, especially in the context of an increasing diversity of organic resources and development of minimum tillage. Furthermore, management of soil organic matter must be designed not only to consider organic matter as a source of plant nutrients but also to foster carbon sequestration or prevent soil erosion. Consequently, interactions between several ecosystem services have to be analysed (Kirkby et al. 2014; Noellemeyer and Six 2015). Here also, user-friendly decision-support systems have to be developed.

Integrating biological input-based farming systems in local or regional circular economies raises specific research questions. Most are rooted in industrial ecology and require assessing characteristics and effects of products with different potential uses (e.g. biogas production), reuse and recycling (e.g. providing organic matter to soils), etc. Moving from the farm to the local or regional level to close material and energy cycles requires coordination among agricultural stakeholders and stakeholders in other sectors (see Sect. 3.2). Considering the local or regional characteristics of food systems, Fernandez-Mena et al. (2016) argue that the scientific field of "agro-industrial ecology" should be developed to provide methods and decision-support systems to analyse, design and assess recycling loops and explore circular-economy options.

\subsection{Biodiversity-based farming systems in globalised commodity-based food systems and territorial socio-economic contexts}

We identified three main consistent agriculture models by considering possible or synergetic interactions between biodiversity-based farming systems and the different socioeconomic contexts explored. Importantly, the lack of attractive markets for certain key crops, such as legumes, which allow for diversification of cropping systems, is an important "lockin" which impedes development of biodiversity-based farming systems (Magrini et al. 2016; Meynard et al. 2013). In each of the three agriculture models described below, this problem is solved by different non-exclusive diversification levers: alternative food systems, circular economies (e.g. exchange of products between farms) or integrated landscape approaches. Below, we present the three agriculture models, their common research issues and their specific research issues.

The first agriculture model corresponds to biodiversitybased farming systems developed in socio-technical niches, such as those related to conservation agriculture, agro-forestry, integrated crop-livestock systems and self-sufficient grassland-based livestock systems (upper left quadrant of Fig. 4). When no other solution exists or prices are attractive, farmers sell agricultural products in globalised commodity-based food supply chains, like the two first types of agriculture models. Diversified crops, which are difficult to sell in this type of supply chain, are fed to animals (on the same farm or by trading between crop and animal farms), or directly sell to consumers, which is a form of alternative food system directly managed by the farmer.

In the second model of biodiversity-based agriculture, diversified farming systems expand widely or are maintained in a given territory due to development of alternative food systems at the local, regional or global level via adapted valueladen supply chains (upper right quadrant of Fig. 4, see Sect. 3.3). This model of agriculture can be based on developing both alternative food systems and circular economies (as represented in Fig. 4) to increase opportunities to diversify farming systems. This provides opportunities to develop local or regional "integrated food-energy systems" (Metereau and Figuière 2014). The objective is then to develop synergies between food and energy productions with positive influence on ecosystem services (e.g. Werling et al. 2014).

Developing an integrated landscape approach, which combines collective multi-service landscape management and the development of alternative food systems and circular economies, corresponds to the third agriculture model involving biodiversity-based farming systems (upper right quadrant in Fig. 4). Integrating these three diversification levers seemed to us the best way to develop biodiversity-based farming systems and their expected benefits from field and farm to local, regional and global levels. This should help to address sustainable management of the Food/Non-food/Natural resources nexus, which determines local-to-global sustainability of agriculture (Kline et al. 2016; Marsden 2012; Robledo-Abad et al. 2016).

Even though the first agriculture model involving biodiversity-based farming systems represents relatively few farming systems, it does exist in most OECD countries (upper left quadrant of Fig. 4). The two latter agriculture models (upper right quadrant of Fig. 4), particularly the last one, are currently very marginal or do not really exist in many regions of developed countries. In the last two agriculture models, 
some raw agricultural products of farming systems may be still sold through globalised commodity-based food supply chains (Fig. 4). Alternative and globalised commodity-based food systems thus co-exist (see Sect. 5.5).

The three agriculture models involving biodiversity-based farming systems have common research issues. First, breeding of cash-crop cultivars adapted to intercropping and use of few external inputs, and of cover plants selected to provide targeted functions or services (e.g. soil structuring, phosphorus solubilisation, stimulation of beneficial soil biological activity) in mixture or crop sequence, are key research areas (Gaba et al. 2014; Reeve et al. 2016). To ensure adaptation of species or cultivars to specific sites and functions, new breeding objectives and programmes should be developed. Developing local or regional participatory breeding is a promising approach for which research must develop adapted knowledge and procedures (Costanzo and Barberi 2014).

Second, research must provide useful knowledge to develop adaptive management of biodiversity-based farming systems and multi-service landscapes. The challenge for research is to develop generic agro-ecological knowledge about relationships between management practices, associated biodiversity and ecosystem services and to transform them into actionable knowledge in specific action situations (Geertsema et al. 2016; Duru et al. 2015a; Caron et al. 2014; Landis 2016; Šumane et al. 2017; Werling et al. 2014). Several research strategies based on different (agro-)ecological approaches can provide such actionable knowledge, such as (i) functional ecology approaches (response-and-effect plant traits) to identify species/cultivar growth, either alone or in mixtures (Duru et al. 2015a; Faucon et al. 2017; Gaba et al. 2014a); (ii) landscape ecology approaches, possibly combined with functional ecology (e.g. Fahrig et al. 2011; Schellhorn et al. 2015), to analyse and estimate relationships between landscape characteristics and ecological processes; (iii) network-based approaches to analyse and manage impacts of human activities on ecological networks (Bohan et al. 2016; Hagen et al. 2012) and (iv) environmental gradient approaches to analyse and estimate relationships between agricultural practices and species distribution (e.g. for weed management; Gaba et al. 2014). The additional potential and possible integration of these different research strategies remain to be analysed. Strategies are also needed to manage slow variables related to soil characteristics (Drinkwater and Snapp 2007; Reeve et al. 2016). Operational knowledge to develop strategies to use external inputs (chemical and biological) which support (e.g. organic fertilisers) or do not impair (e.g. pesticides) ecosystem services is another key research topic (Reeve et al. 2016).

In addition to generic knowledge about the functioning of agricultural ecosystems and landscapes, research should also develop participatory procedures and operational tools to design and assess diversified farming systems and landscapes, possibly based on modelling, and operational methods to monitor their dynamics (Duru et al. 2015a, b; Freeman et al. 2015; Mastrangelo et al. 2014; Reed et al. 2016; Voinov et al. 2016). For example, research could develop tools to design the spatial distribution and management of non-crop habitats at farm and landscape levels (e.g. Tzilivakis et al. 2016). More generally, how new information and communication technologies (ICT) can be used to render scientific knowledge accessible and operational or to collect experience feedback from farmers have to be explored (Dowd et al. 2014; Duru et al. 2015a).

In the second agriculture model involving biodiversitybased farming systems, a specific research issue in agronomy is to develop useful knowledge to help local/regional stakeholders design and manage alternative food systems to promote soil, plant, animal and ecosystem health and, in turn, human health (Reeve et al. 2016; Vieweger and Döring 2014) and its resilience (Döring et al. 2014). In this model, developing integrated food-energy systems requires extending analysis, design and assessment of agro-industrial ecology approaches (Metereau and Figuière 2014; see Sect. 4.2). As for circular economies in general (Ghiselli et al. 2014), organising exchanges between farms raises important governance and social organisation issues for socio-economic research (Martin et al. 2016; Moraine et al. 2016).

To support development of the third agriculture model involving biodiversity-based farming systems, agronomic research must provide "actionable knowledge" and participatory methods for collective design of socially relevant integration of circular economies, alternative food systems and collective management of multi-service landscapes (Duru et al. 2015a, b; Geertsema et al. 2016; Mastrangelo et al. 2014). Importantly, to support integrated landscape approaches, research must develop methods to analyse trade-offs between objectives (including ecosystem services) and define associated social compromises (e.g. Rapidel et al. 2015; Sect. 3.4). Regarding management of multi-service landscapes, one key research issue is to clarify the relative effects of landscape configuration and composition and those of cropping systems (field level) for different ecosystem services, both during farming system transition and after biodiversity-based farming systems are well-established (e.g. Duru et al. 2015a; Emmerson et al. 2016; Tamburini et al. 2016). Research should analyse and highlight trade-offs, synergies or neutral relationships between ecosystem services from field to landscape levels according to the biophysical and technical contexts (Mastrangelo et al. 2014; Wu 2013).

\section{Discussion}

\subsection{Added value of the analytical framework}

To date, most studies of farming systems and agriculture models have addressed only (i) the diversity of their 
biotechnical functioning or socio-economic contexts (references in Sects. 2 and 3), (ii) specific types of farming systems (Sect. 2) or specific socio-economic contexts (Sect. 3) or (iii) specific combinations of the two dimensions (e.g. simplified or diversified organic systems in industrial globalised or alternative food systems in Darnhofer et al. 2010). Our framework addresses both the biotechnical functioning of farming systems (vertical axis; Fig. 4) and the characteristics of their socio-economic context (horizontal axis; Fig. 4) across all gradients of both dimensions to characterise key agriculture models.

Our new analytical framework (Fig. 4) allows a variety of existing or future agriculture models to be identified and described. It highlights and clarifies the wide diversity of agriculture models currently hidden behind coarse descriptors such as ecological intensification, "agro-ecology" and "organic agriculture". These classifications usually encompass several of the six agriculture models.

Organic agriculture is often presented as a promising path to sustainable agriculture. However, organic farming systems are included in all the five agriculture models not based on chemical inputs. Organic farming systems based on biological inputs and developed in industrial globalised food systems represent the "conventionalisation" of organic farming systems (Bacon et al. 2012; Darnhofer et al. 2010).

Products with labels of origins can be produced in all six agriculture models identified (Marsden et al. 2000; Murdoch et al. 2000). They can be produced by input-based agricultural farming systems and traded through globalised commoditybased food systems with low social, spatial and ecological embeddedness and little or no additional added value for farmers or the local/regional economy (e.g. geographical indications oriented to economic efficiency; Parrott et al. 2002). They also can be traded in short or long supply chains in alternative food systems with strong social, spatial or ecological embeddedness and, in turn, equally distribute added value to all participants (e.g. the French cheese "Comte" protected designation of origin, Bowen 2010; Parrott et al. 2002). Accordingly, our analytical framework of agriculture models greatly helps to clarify the main characteristics of these different farming systems and socio-economic contexts in both absolute and relative terms. It can also help to clarify the multi-level structure of the agri-food sector, in which the boundaries between local and "global" are often blurred (Murdoch et al. 2000). Using the concept of embeddedness to characterise the socio-economic contexts which determine farming system functioning provides criteria useful for finely describing agriculture models.

\subsection{Generic character of the analytical framework and agriculture models}

We developed the analytical framework to classify agriculture models which address environmental issues raised by the development of industrial agriculture. Accordingly, it is adapted for analysing agriculture models in regions of countries in which industrial agriculture developed, such as intensive agricultural zones in OECD countries. Because the concepts used to develop this framework are generic, it is suitable for analysing the diversity of agriculture models in developing and tropical countries, where socio-economic limitations (e.g. investment capacity) make it challenging to follow the paradigm of industrial agriculture. For example, it could be easily adapted to the autonomous farming systems based on manual human and animal labour which exist in these countries.

The six agriculture models identified are "archetypes" that help render the diversity of models tractable and identify associated specific and common research issues. They are, to a certain degree, arbitrary and depend on the type of analysis chosen and the questions addressed. For example, we did not present agriculture models corresponding to input-based or biodiversity-based farming systems involved in sectoral landscape approaches, as they may not emphasise specific research questions.

These archetypes, which are useful for analysing diversity, should not hide the wide diversity in the "real world". These archetypes lie on continuous gradients of biotechnical functioning of farming systems and their socio-economic contexts, as represented by shaded areas in Fig. 4 .

We believe that the analytical framework and agriculture models will help to finely describe the diversity of agricultures. Both could change according to results of future studies that would use or challenge them. For example, the lists of farming systems, territorial contexts and agriculture models are not definitive and exhaustive; they should be refined and extended.

\subsection{Technologies and bioeconomy in agriculture models}

All of the agriculture models identified require adapted cultivars, farm machinery and ICT. While precision-agriculture technologies are well adapted to input-based farming systems, the equipment and ICT required for the other models remain to be finely defined to determine whether the models have specific requirements.

All of the agriculture models identified can help develop a bioeconomy, which has gained importance in both research and policy debates in the past decade and is frequently argued to be a key part of the solution to multiple grand challenges (Bugge et al. 2016). Input-based agriculture models are more oriented towards developing a global bioeconomy focused on processing and upgrading biological raw materials, as well as on establishing new associated large-scale supply chains. In agriculture models more integrated within territorial contexts (right half quadrant of Fig. 4), much attention may be paid to developing a bioeconomy at local or regional levels (e.g. through circular economies) via sustainable management of 
the nexus of Food/Non-food/Natural resources. Here, the bioecology vision of sustainability prevails, i.e. promoting biodiversity and avoiding monocultures and soil degradation to optimise energy efficiency and production (Bugge et al. 2016).

\subsection{Multi-level and multi-criteria assessments of agriculture models}

Public funding of one or several co-existing agriculture models may depend on sound assessment of their sustainability performances. To support public decision-making, research must develop adapted multi-criteria approaches that consider both static and dynamic dimensions of sustainability: (i) levels of economic, social and environmental performances, as well as agricultural production and (ii) the ability to ensure long-term sustainability of these levels, i.e. their resilience (Duru and Therond 2014).

Regarding the static dimension of sustainability, multicriteria approaches should help consider levels of and tradeoffs between metabolic performances (resource-use efficiency and associated negative environmental impacts), ecosystem services and disservices, biodiversity conservation and economic and social (including health) performances (e.g. Barot et al. 2017; German et al. 2016; Moraine et al. 2016) at key levels of decision-making, such as the cropping system, farming system, local, regional, national and global levels (Caron et al. 2014, Ewert et al. 2011). They also need to help identify trade-offs between ecosystem services to farmers and to society from field to global levels.

Regarding the dynamic dimension of sustainability, multicriteria approaches should (i) clarify properties of the agriculture models that influence their resilience and (ii) assess the resilience of the models to socio-economic and biophysical hazards (Duru and Therond 2014). They should help to determine whether agriculture models based on biodiversity and territorial contexts are more economically and biophysically resilient.

These multi-criteria and multi-level assessment approaches should explicitly address the great challenges of agriculture, such as influence on and adaptation to climate changes; scarcity of non-renewable resources (including phosphorus); food, energy and technological security; and sovereignty and biodiversity conservation. More generally, they should allow static and dynamic sustainability of different combinations of agriculture models to be assessed at local, regional and global levels in light of the nexus of Food/Non-food/Natural resources.

\subsection{Co-existence of agriculture models}

Agriculture models can co-exist at different organisational levels: farming system, territory and food system. They can co-exist as different enterprises within the same farm, e.g. a livestock enterprise using external inputs and supplying the globalised food system combined with a crop enterprise following conservation agriculture and fully or partially supplying an alternative food system. They often co-exist at local and regional levels and in local or regional rural development projects. They can also co-exist within a given food supply chain in which economic agents use their resources to manage the globalised generic commodity-based supply chain and alternative food systems (Bloom and Hinrichs 2011; Lerman 2012; Murdoch et al. 2000; Sonnino and Marsden 2006). Our framework can be used to represent the diversity of agriculture models in a farming system (as different enterprises), given territory, food system or territorial development project.

As different agriculture models can and do co-exist in the same area, conditions under which they co-exist should also be clarified. More precisely, biophysical and socio-economic trade-offs, synergies or neutral co-existence at farm, local, regional, food system and global levels have to be analysed (Hervieu and Purseigle 2015; Horling and Marsden 2011; Lyson and Guptill 2004; Marsden 2012; Murdoch et al. 2000; Sonnino and Marsden 2006). It is necessary to clarify to what extent and under what conditions the presence of input-based farming systems in the landscape is compatible with the objectives of developing ecosystem services at this level. It is also necessary to clarify to what extent co-existence of input-based and biodiversity-based farming systems in the landscape could help reach the objective of biodiversity conservation. It is important to keep in mind that this latter objective provides the greatest challenges to the sustainability of input-based farming system strategies. Regarding biodiversity conservation, the scientific challenge in agronomy is to contribute to and advance the intense debate about the relative merits of "land sharing versus land sparing" strategies (Barral et al. 2015; Ekroos et al. 2016; Kremen 2015) given individual and combined effects of different agriculture models on biodiversity and associated ecosystem services. Conditions of competitive or collaborative relationships and hybridisation between alternative and globalised commoditybased food systems are also to be analysed (Bloom and Hinrichs 2011; Lerman 2012; Murdoch et al. 2000; Sonnino and Marsden 2006; Sect. 3.3).

It is also necessary to analyse the extent to which agriculture models can complement each other in addressing the great challenges in agriculture (see previous section) and, more generally, the sustainable management of the nexus of Food/Non-food/Natural resources (Kline et al. 2016; Marsden 2012; Robledo-Abad et al. 2016; Sect. 4.3). Multi-criteria approaches, discussed in the previous section, should enable assessment of sustainability performances of each agriculture model and also of combinations of different models at local, regional or global levels. 


\subsection{Transitions between agriculture models}

Finally, conditions for shifting from one agriculture model to another should be analysed and clarified to determine the required incremental, system or transformational changes (Park et al. 2012). Current research continues to support changing the dominant agriculture model: chemical input-based farming systems embedded in globalised commodity-based food systems. Support for developing the two models involving biological input-based farming systems is growing strongly. Research on developing biodiversity-based farming systems needs to be strengthened, particularly development of territorially integrated forms of agriculture based on diversified farming systems (DeLonge et al. 2016; Levidow et al. 2014; Vanloqueren and Baret 2009).

Developing biodiversity-based farming systems and multiservice landscapes raises questions about how to manage the "transformational" transition from specialised systems and simplified landscapes to well-established diversified ones. During this transition, variability in ecosystem services may increase greatly until slow variables reach states which provide ecosystem services at expected levels and degrees of biophysical resilience and stability. Uncertainties due to managing diversified farming systems and landscapes may increase during this transition (Duru et al. 2015a). Consequently and above all, adaptive management strategies of farming systems and landscapes are necessary to manage this type of transition (see Sects. 2.3, 3.4 and 4.3).

Although this article focused on agronomic research issues, research is also needed on social, institutional, political and governance conditions for developing and managing diversified farming systems, circular economies, alternative food systems and integrated landscape approaches (see, e.g. Bacon et al. (2012) concerning farming systems and Sects. $3.2,3.3$, and 3.4 for the three types of territorial contexts explored).

\section{Conclusion}

Given weaknesses of current classifications, we reviewed the literature to develop a sound analytical framework to classify agriculture models seeking to address environmental issues arising from the development of industrial agriculture. It allows assessing the extent to which farming systems are based on external inputs or ecosystem services and are integrated into globalised commodity-based food systems or territorial socio-economic contexts such as circular economies, alternative food systems and integrated landscape approaches. Our framework addresses biotechnical functioning of farming systems and characteristics of their socio-economic contexts along the entire gradient of each dimension to identify and describe different key agriculture models.
Our analytical framework enabled us to identify six key agriculture models which promote greater sustainability and raise agronomic research issues. They describe a diversity of archetypes of agriculture models which hide behind terms such as organic agriculture or which exist under an umbrella of concepts, such as sustainable intensification or agroecology.

Our analytical framework led us to identify agronomic knowledge gaps of each agriculture model and transversal ones, such as conditions for their co-existence from farm, local, regional and global levels. For agriculture models involving chemical input- and biological input-based farming systems, development of operational knowledge about the best management practices to follow to apply the Right Product, Right Rate, Right Time, and Right Place remains a scientific challenge. When these farming systems are involved in circular economies, agro-industrial ecology is required to provide decision-support systems to analyse, design and assess circular economy options. For the three agriculture models involving biodiversity-based farming systems, the main agronomic research issues involve development of (i) breeding procedures for cultivars adapted to provide targeted ecosystem services in different production situations; (ii) actionable agro-ecological knowledge in specific production situations about relationships between management practices, associated biodiversity and ecosystem services; and (iii) participatory procedures and operational tools to design and assess diversified farming systems and landscapes and to monitor their dynamics. Biodiversity-based farming systems involved in circular economies and alternative food systems require operational knowledge to develop integrated foodenergy systems. When involved in integrated landscape approaches, knowledge is required to develop integrated management of the Food/Non-food/Natural resources nexus.

Assessing static and dynamic sustainability of these agriculture models requires developing multi-level and multicriteria assessment methods. The latter should allow sustainability performances of different combinations of agriculture models to be assessed at local, regional and global levels in light of the nexus of Food/Non-food/Natural resources. Public funding of research on these agriculture models will determine how much they can develop: "the types of research that are conducted influence the types of knowledge, technology and farming practices that are deemed legitimate and which are profitable" (Hufnagl-Eichiner et al. 2011)!

Finally, our analysis of key research issues associated with and transversal to the identified agriculture models focused on agronomy, but issues in the social and human sciences also need to be analysed. More complete understanding and development of methods which support innovation dynamics for each agriculture model and their co-existence will likely require developing social-ecological and transdisciplinary approaches. 
Acknowledgements This study was carried out by a working group of the division "Environment and Agronomy" of INRA.

Open Access This article is distributed under the terms of the Creative Commons Attribution 4.0 International License (http:// creativecommons.org/licenses/by/4.0/), which permits use, duplication, adaptation, distribution and reproduction in any medium or format, as long as you give appropriate credit to the original author(s) and the source, provide a link to the Creative Commons license and indicate if changes were made.

\section{References}

Alabouvette C, Olivain C, Steinberg C (2006) Biological control of plant diseases: the European situation. Eur J Plant Pathol 114:329-341

Albrecht C, Johnson R, Hamann S, Sneyd L (2013) Toward alternative food systems development: exploring limitations and research opportunities. Journal of Agriculture, Food Systems \& Community Development 3:151-159

Ali MH, Talukder MSU (2008) Increasing water productivity in crop production - a synthesis. Agr Water Manage 95:1201-1213. doi: 10.1016/j.agwat.2008.06.008

Altieri M (1999) The ecological role of biodiversity in agroecosystems. Agr Ecosyst Environ 74:19-31. doi:10.1016/S0167-8809(99) 00028-6

Altieri MA, Funes-Monzote FR, Petersen P (2012) Agroecologically efficient agricultural systems for smallholder farmers: contributions to food sovereignty. Agron Sustain Dev 32:1-13. doi:10.1007/s13593011-0065-6

Anbumozhi V, Radhakrishnan J, Yamaji E (2005) Impact of riparian buffer zones on water quality and associated management considerations. Ecol Eng 24:517-523. doi:10.1016/j.ecoleng.2004.01.007

Arizpe N, Giampietro M, Ramos-Martin J (2011) Food security and fossil energy dependence: an international comparison of the use of fossil energy in agriculture (1991-2003). Crit Rev Plant Sci 30:45-63

Bacon CM, Getz C, Kraus S et al (2012) The social dimensions of sustainability and change in diversified farming systems. Ecol Soc. doi: 10.5751/ES-05226-170441

Barot S, Yé L, Abbadie L et al (2017) Ecosystem services must tackle anthropized ecosystems and ecological engineering. Ecol Eng 99: 486-495. doi:10.1016/j.ecoleng.2016.11.071

Barral MP, Rey Benayas JM, Meli P, Maceira NO (2015) Quantifying the impacts of ecological restoration on biodiversity and ecosystem services in agroecosystems: a global meta-analysis. Agric Ecosyst Environ 202:223-231. doi:10.1016/j.agee.2015.01.009

Beketov MA, Kefford BJ, Schäfer RB, Liess M (2013) Pesticides reduce regional biodiversity of stream invertebrates. PNAS 2:0-1. doi:10. 1073/pnas.1305618110

Beman JM, Arrigo K, Matson PM (2005) Agricultural runoff fuels large phytoplankton blooms in vulnerable areas of the ocean. Nature 434: 211-214

Bennett AJ, Bending GD, Chandler D, Hilton S, Mills P (2012) Meeting the demand for crop production: the challenge of yield decline in crops grown in short rotations. Biol Rev 87:52-71. doi:10.1111/j. 1469-185X.2011.00184.x

Benoît M, Rizzo D, Marraccini E, Moonen AC, Galli M, Lardon S, Rapey H, Thenail C, Bonari E (2012) Landscape agronomy: a new field for addressing agricultural landscape dynamics. Landsc Ecol 27:1385-1394. doi:10.1007/s10980-012-9802-8

Benton TG, Vickery JA, Wilson JD (2003) Farmland biodiversity: is habitat heterogeneity the key? Trends Ecol Evol 18:182-188. doi: 10.1016/S0169-5347(03)00011-9
Berthet ET, Bretagnolle V, Segrestin B (2012) Analyzing the design process of farming practices ensuring little bustard conservation: lessons for collective landscape management. J sustain agr 36:319-336

Bianchi FJJA, Booij CJH, Tscharntke T (2006) Sustainable pest regulation in agricultural landscapes: a review on landscape composition, biodiversity and natural pest control. Proc R Soc B Biol Sci 273: 1715-1727. doi:10.1098/rspb.2006.3530

Biggs R et al (2012) Toward principles for enhancing the resilience of ecosystem services. Annu Rev Environ Resour 37:421-448

Billen G, Garnier J, Lassaletta L (2013) The nitrogen cascade from agricultural soils to the sea: modelling $\mathrm{N}$ transfers at regional watershed and global scales. Phil Trans R Soc B 368:0123. doi:10.1098/rstb. 2013.0123

Billen G, Lassaletta L, Garnier J (2014a) A biogeochemical view of the global agro-food system: nitrogen flows associated with protein production, consumption and trade. Glob Food Secur 3:209-219

Billen G, Lasseletta L, Garnier J (2014b) A biogeochemical view of the global agro-food system: nitrogen flows associated with protein production, consumption and trade. Global Food Secur 3:209-219. doi:10.1016/j.gfs.2014.08.003i

Billen G, Lassaletta L, Garnier J (2015) A vast range of opportunities for feeding the world in 2050: trade-off between diet, $\mathrm{N}$ contamination and international trade. Environ Res Lett 10:025001

Bloom JD, Hinrichs CC (2011) Informal and formal mechanisms of coordination in hybrid food value chains. J Agric Food Syst Community Dev 1(4):143-156

Bodirsky BL, Popp A, Weindl I, Dietrich JP, Rolinski S, Scheiffele L, Schmitz C, Lotze-Campen H (2012) N2O emissions from the global agricultural nitrogen cycle - current state and future scenarios. Biogeosciences 9:69-97

Bodirsky BL, Popp A, Lotze-Campen H, et al. (2014) Reactive nitrogen requirements to feed the world in 2050 and potential to mitigate nitrogen pollution. Nat Commun 5:3858. doi:10.1038/ncomms4858

Bohan DA, Bonte D, Ma A, Macfadyen S, Martinet V, McInerny GJ, Montoya JM, Mulder C, Pascual U et al (2016) Networking our way to better ecosystem service provision. Trends Ecol Evol 31:112-121 doi:10.1016/j.tree.2015.12.003

Bommarco R, Kleijn D, Potts SG (2013) Ecological intensification: harnessing ecosystem services for food security. Trends Ecol Evol 28:230-238. doi:10.1016/j.tree.2012.10.012

Borin M, Passoni M, Thiene M, Tempesta T (2010) Multiple functions of buffer strips in farming areas. Eur J Agron 32:103-111. doi:10.1016/ j.eja.2009.05.003

Bourguet D, Guillemaud T (2016) The hidden and external costs of pesticide use. Sustain Agric Reviews 19:35-120

Bowen S (2010) Embedding local places in global spaces: geographical indications as a territorial development strategy. Rural Sociol 75: 209-243. doi:10.1111/j.1549-0831.2009.00007.x

Bowen S, Mutersbaugh T (2014) Local or localized? Exploring the contributions of Franco-Mediterranean agrifood theory to alternative food research. Agric Human Values 31:201-213. doi:10.1007/ s10460-013-9461-7

Bugge M, Hansen T, Klitkou A (2016) What Is the Bioeconomy? A Review of the Literature. Sustainability 8(7):2-22. doi:10.3390/ su8070691

Camarguo JA, Alonso A (2006) Ecological and toxicological effects of inorganic nitrogen pollution in aquatic ecosystems: a global assessment. Environ Int 32:831-849

Campbell H (2009) Breaking new ground in food regime theory: Corporate environmentalism, ecological feedbacks and the "food from somewhere" regime? Agric Human Values 26:309-319. doi: 10.1007/s10460-009-9215-8

Capone R, Bilali H, El Debs P, Gianluigi C, Noureddin D (2014) Food system sustainability and food security: connecting the dots. J Food Secur 2:13-22. doi:10.12691/jfs-2-1-2 
Caron P, Biénabe E, Hainzelin E (2014) Making transition towards ecological intensification of agriculture a reality: the gaps in and the role of scientific knowledge. Curr Opin Env Sust 8:44-52

Cordeau S, Triolet M, Wayman S, Steinberg C, Guillemin JP (2016) Bioherbicides: dead in the water? A review of the existing products for integrated weed management. Crop Prot 87:44 49. doi:10.1016/ j.cropro.2016.04.016

Cordell D, Drangert JO, White S (2009) The story of phosphorus: global food security and food for thought. Global Environ Chang 19:292305. doi:10.1016/j.gloenvcha.2008.10.009

Cordell D, Rosemarin A, Schröder JJ, Smit AL (2011) Towards global phosphorus security: a systems framework for phosphorus recovery and reuse options. Chemosphere 84:747-758. doi:10.1016/j. chemosphere.2011.02.032

Correll DL (2005) Principles of planning and establishment of buffer zones. Ecol Eng 24:433-439. doi:10.1016/j.ecoleng.2005.01.007

Costanza R, Arge R, Groot RD et al (1997) The value of the world's ecosystem services and natural capital. Nature 387:253-260

Costanzo A, Barberi P (2014) Functional agrobiodiversity and agroecosystem services in sustainable wheat production. A review. Agron Sustain Dev 34:327-348. doi:10.1007/s13593-013-0178-1

Crane TA, Roncoli C, Hoogenboom G (2011) Adaptation to climate change and climate variability: the importance of understanding agriculture as performance. NJAS-Wagen J Life Sc 57:179-185. doi:10.1016/j.njas.2010.11.002

Daily G (1997) Daily - What Are Ecosystem Services.pdf. Nature's Serv, Arlington, pp 1-19

Darnhofer I, Lindenthal T, Bartel-Kratochvil R, Zollitsch W (2010) Conventionalisation of organic farming practices: from structural criteria towards an assessment based on organic principles. A review. Agron Sustain Dev 30:67-81. doi:10.1051/agro/2009011

DeLonge MS, Miles A, Carlisle L (2016) Investing in the transition to sustainable agriculture. Environ Sci Pol 55:266-273

Döring TF, Vieweger A, Pautasso M, Vaarst M, Finckh MR, Wolfe MS (2014) Resilience as a universal criterion of health. J Sci Food Agr 95:455-465. doi:10.1002/jsfa.6539

Dowd A, Marshall N, Fleming A, Jakku E, Gaillard E, Howden M (2014) The role of networks in transforming Australian agriculture. Nat Clim Chang 4:558-563. doi:10.1038/nclimate2275

Drinkwater LE, Snapp SS (2007) Nutrients in agroecosystems: rethinking the management paradigme. Adv Agron 92. doi:10.1016/S00652113(04)92003-2

Duru M, Therond O (2014) Livestock system sustainability and resilience in intensive production zones: which form of ecological modernization? Reg Environ Chang 15:1651-1665

Duru M, Therond O, Martin G, Martin-Clouaire R, Magne M, Justes E, Journet EP, Aubertot JN, Savary S, Bergez JE, Sarthou JP (2015a) How to implement biodiversity-based agriculture to enhance ecosystem services: a review. Agron Sustain Dev. doi:10.1007/s13593015-0306-1

Duru M, Therond O, Fares M (2015b) Designing agroecological transitions; a review. Agron Sustain Dev 35:0. doi:10.1007/s13593-0150318-x

Ekroos J, Ödman AM, Andersson GKS, Birkhofer K, Herbertsson L, Klatt BK, Olsson O, Olsson PA, Persson AS, Prentice HC, Rundlöf M, Smith HG (2016) Sparing land for biodiversity at multiple spatial scales. Front Ecol Evol 3:1-11. doi:10.3389/fevo.2015. 00145

Emmerson M, Morales MB, Oñate JJ et al (2016) How agricultural intensification affects biodiversity and ecosystem services. Adv Ecol Res 55. doi:10.1016/bs.aecr.2016.08.005

Ewert F, Van Ittersum MK, Heckelei T, Therond O, Bezlepkina I, Andersen E (2011) Scale changes and model linking methods for integrated assessment of agri-environmental systems. Agriculture Ecosystems and Environment 142:6-17. doi:10.1016/j.agee.2011. 05.016
Fahrig L, Baudry J, Brotons L, Burel FG, Crist TO, Fuller RJ, Sirami C, Siriwardena GM, Martin JL (2011) Functional landscape heterogeneity and animal biodiversity in agricultural landscapes. Ecol Lett 14:101-112

Faucon M-P, Houben D, Lambers H (2017) Plant functional traits: soil and ecosystem services. Trends Plant Sci xx:1-10. doi:10.1016/j. tplants.2017.01.005

Fernandez-Mena H, Nesme T, Pellerin S (2016) Towards an agroindustrial ecology: a review of nutrient flow modelling and assessment tools in agro-food systems at the local scale. Sci Total Environ 543:467-479

Foley JA, Defries R, Asner GP et al (2005) Global Consequences of Land Use. Science 309:570-575

Foley JA, Ramankutty N, Brauman KA, Cassidy ES, Gerber JS, Johnston M, Mueller ND, O'Connel C, Ray DK, West PC, Balzer C, Bennett EM, Carpenter SR, Hill J, Monfreda C, Polasky S, Rockström J, Sheehan J, Siebert S, Tilman D, Zaks DPM (2011) Solutions for a cultivated planet. Nature 478:337-342. doi:10.1038/nature10452

Foran T, Butler JRA, Williams LJ, Wanjura WJ, Hall A, Carter L, Carberry PS (2014) Taking complexity in food systems seriously: an interdisciplinary analysis. World Dev 61:85-101

Freeman OE, Duguma LA, Minang PA (2015) Operationalizing the integrated landscape approach in practice. Ecol Soc. doi:10.5751/ES07175-200124

Gaba S, Lescourret F, Boudsocq S, Enjalbert J, Hinsinger P, Journet EP, Navas ML, Wery J, Louarn G, Malézieux E, Pelzer E, Prudent M, Ozier-Lafontaine H (2014a) Multiple cropping systems as drivers for providing multiple ecosystem services: from concepts to design. Agron Sustain Dev 35:607-623. doi:10.1007/s13593-014-0272-z

Gaba S, Fried G, Kazakou E, Chauvel B, Navas ML (2014b) Agroecological weed control using a functional approach: a review of cropping systems diversity. Agron Sustain Dev 34:103-119. doi: 10.1007/s13593-013-0166-5

Gaba S, Gabriel E, Chadœuf J, Bonneu F, Bretagnolle V (2016) Herbicides do not ensure for higher wheat yield, but eliminate rare plant species. Sci Rep 6:30112. doi:10.1038/srep30112

Galloway JN, Aber JD, Erisman JW, Seitzinger SP, Howarth RW, Cowling EB, Cosby BJ (2003) The nitrogen cascade. Bioscience 53:341-356

Galloway JN, Dentener FJ, Capone DG, Boyer EW, Howarth RW, Seitzinger SP, Asner GP, Cleveland CC, Green PA, Holland EA, Karl DM, Michaels AF, Porter JH, Townsend AR, Vorosmarty CJ (2004) Nitrogen cycles: past, present, and future. Biogeochemistry 70:153-226

Galloway JN, Townsend AR, Erisman JW, Bekunda M, Cai Z, Freney JR, Martinelli LA, Seitzinger SP, Sutton MA (2008) Transformation of the nitrogen cycle: recent trends, questions, and potential solutions. Science 320:889-892. doi:10.1126/science.1136674

Gámez-Virués S, Perović DJ, Gossner MM, Börschig C, Blüthgen N, de Jong H, Simons NK, Klein AM, Krauss J, Maier G, Scherber C, Steckel J, Rothenwöhrer C, Steffan-Dewenter I, Weiner CN, Weisser W, Werner M, Tscharntke T, Westphal C (2015) Landscape simplification filters species traits and drives biotic homogenization. Nat Commun 6:8568. doi:10.1038/ncomms9568

Gan-Mor S, Matthews GA (2003) Recent developments in sprayers for application of biopesticides - an overview. Biosyst Eng 84:119-125. doi:10.1016/S1537-5110(02)00277-5

Garbach K, Milder JC, DeClerck FAJ, Montenegro de Wit M, Driscoll L, Gemmill-Herren B (2016) Examining multi-functionality for crop yield and ecosystem services in five systems of agroecological intensification. Intern J Agr Sustain 5903:1-22. doi:10.1080/ 14735903.2016.1174810

Geertsema W, Rossing WAH, Landis DA, Bianchi FJJA, van Rijn PCJ, Schaminée JHJ, Tscharntke T, van der Werf W (2016) Actionable knowledge for ecological intensification of agriculture. Front Ecol Environ 14:209-216. doi:10.1002/fee.1258 
Geiger F et al (2010) Persistent negative effects of pesticides on biodiversity and biological control potential on European farmland. Basic Appl Ecol 11:97-105

German RN, Thompson CE, Benton TG (2016) Relationships among multiple aspects of agriculture's environmental impact and productivity: a meta-analysis to guide sustainable agriculture. Biol Rev. doi:10.1111/brv.12251

Ghisellini P, Cialani C, Ulgiati S (2014) A review on circular economy: the expected transition to a balanced interplay of environmental and economic systems. J Clean Prod 114:11-32. doi:10.1016/j.jclepro. 2015.09.007

Gibbons D, Morrissey C, Mineau P (2014) A review of the direct and indirect effects of neonicotinoids and fipronil on vertebrate wildlife, (Mineau 2011). Envir Sci Pollut Res Int. doi:10.1007/s11356-014$3180-5$

Giles J (2005) Nitrogen study fertilizes fears of pollution. Nature 433: 791. doi:10.1038/433791a

Giller KE, Andersson JA, Corbeels M, Kirkegaard J, Mortensen D, Erenstein O, Vanlauwe B (2015) Beyond conservation agriculture. Front Plant Sci 6:1-14. doi:10.3389/fpls.2015.00870

Glare T, Caradus J, Gelernter W, Jackson T, Keyhani N, Köhl J, Marrone P, Morin L, Stewart A (2012) Have biopesticides come of age? Trends Biotechnol 30:250-258. doi:10.1016/j.tibtech.2012.01.003

Gliessman SR (2007) Agroecology: the ecology of sustainable food systems, Second edn. Lewis Publishers (CRC Press), Boca Raton

Godfray HCJ, Beddington JR, Crute IR, Haddad L, Lawrence D, Muir JF, Pretty J, Robinson L, Toulmin (2010) Food security: the challenge of feeding 9 billion people. Science 327:812-818

Gomiero T, Pimentel D, Paoletti MG (2011) Is there a need for a more sustainable agriculture? Crit Rev Plant Sci 30:6-23

Goulding K, Jarvis S, Whitmore A (2008) Optimizing nutrient management for farm systems. Philos T R Soc B 363:667-680. doi:10. 1098/rstb.2007.2177

Green RE, Cornell SJ, Scharlemann JPW, Balmford A (2005) Farming and the fate of wild nature. Science 307:550-555. doi:10.1126/ science. 1106049

Groot RSD, Alkemade R, Braat L, Hein L, Willemen L (2010) Challenges in integrating the concept of ecosystem services and values in landscape planning, management and decision making. Ecol Complex 7:260-272

Hagen MW, Kissling D, Rasmussen C et al (2012) Biodiversity, species interactions and ecological networks in a fragmented world. Adv Ecol Res 46:89-120. doi:10.1016/B978-0-12-396992-7.00002-2

Hervieu B, Purseigle F (2015) The sociology of agricultural worlds: from a sociology of change to a sociology of coexistence. Revue d'Études en Agriculture et Environnement 96:59-90

Hill SB (1998) Redesigning agroecosystems for environmental sustainability: a deep systems approach. Syst Res Behav Sci 15(5):391-402

Hirel B, Tétu T, Lea PJ, Dubois F (2011) Improving nitrogen use efficiency in crops for sustainable agriculture. Sustainability-Basel 3: 1452-1485. doi:10.3390/su3091452

Hoang VN, Alauddin M (2010) Assessing the eco-environmental performance of agricultural production in OECD countries: the use of nitrogen flows and balance. Nutr Cycl Agroecosys 87:353-368. doi:10.1007/s10705-010-9343-y

Horlings LGG, Marsden TKK (2011) Towards the real green revolution? Exploring the conceptual dimensions of a new ecological modernisation of agriculture that could "feed the world.". Global Environ Chang 21:441-452

Hossard L, Archer DW, Bertrand M et al (2016) A meta-analysis of maize and wheat yields in low-input vs. conventional and organic systems. Agron J 108:1155-1167. doi:10.2134/agronj2015.0512

Hufnagl-Eichiner S, Wolf SA, Drinkwater LE (2011) Assessing socialecological coupling: agriculture and hypoxia in the Gulf of Mexico. Global Environ Chang 21:530-539. doi:10.1016/j.gloenvcha.2010. 11.007
Hynes RK, Boyetchko SM (2006) Research initiatives in the art and science of biopesticide formulations. Soil Biol Biochem 38:845 849. doi:10.1016/j.soilbio.2005.07.003

IAASTD (2009) International assessment of agricultural knowledge, science and technology for development: agriculture at a crossroads. In: BD MI, Herren HR, Wakhungu J, Watson RT (eds) Global report. International Assessment of Agricultural Knowledge, Science and Technology for Development, Island Press, Washington, DC

Ingram J (2008) Agronomist-farmer knowledge encounters: an analysis of knowledge exchange in the context of best management practices in England. Agric Hum Values 25:405-418. doi:10.1007/s10460008-9134-0

Ittersum MKV, Rabbinge R (1997) Concepts in production ecology for analysis and quantification of agricultural input-output combinations. Field Crop Res 52:197-208

Khoury CK, Bjorkman AD, Dempewolf H, Ramirez-Villegas J, Guarino L, Jarvis A, Rieseberg LH, Struik PC (2014) Increasing homogeneity in global food supplies and the implications for food security. P Natl Acad Sci USA 111:4001-4006. doi:10.1073/pnas.1313490111

Kirkby CA, Richardson AE, Wade LJ, Passioura JB, Batten GD, Blanchard C, Kirkegaard JA (2014) Nutrient availability limits carbon sequestration in arable soils. Soil Biol Biochem 68:402-409

Kline KL, Msangi S, Dale VH et al (2016) Reconciling food security and bioenergy: priorities for action. GCB Bioenergy:1-20. doi:10.1111/ gcbb. 12366

Koohafkan P, Altieri MA, Gimenez EH (2012) Green agriculture: foundations for biodiverse, resilient and productive agricultural systems. Int J Agr Sustain 10:61-75. doi:10.1080/14735903.2011.610206

Kraehmer H, van Almsick A, Beffa R, Dietrich H, Eckes P, Hacker E, Hain R, Strek HJ, Stuebler H, Willms L (2014) Herbicides as weed control agents: state of the art. II. Recent achievements. Plant Physiol 166:1132-1148 (2014b)

Kremen C (2015) Reframing the land-sparing/land-sharing debate for biodiversity conservation. Ann N Y Acad Sci. doi:10.1111/nyas. 12845

Kremen C, Iles A, Bacon C (2012) Diversified farming systems: an agroecological, systems-based. Ecol Soc 17:44-63. doi:10.5751/ES05103-170444

Kuisma M, Kahiluoto H, Havukainen J, Lehtonen E, Luoranen M, Myllymaa T, Grönroos J, Horttanainen M (2012) Understanding biorefining efficiency - the case of agrifood waste. Bioresour Technol 135:588-597

Landis DA (2016) Designing agricultural landscapes for biodiversitybased ecosystem services. Basic and Applied Ecology 18:1-12. doi:10.1016/j.baae.2016.07.005

Lassaletta L, Billen G, Grizzetti B, Garnier J, Leach AM, Galloway JM (2014) Food and feed as a driver in the global nitrogen cycle: 50year trends. Biogeochemistry 118:225-241

Le Roux R, Barbault J, Baudry J, Burel F, Doussan I, Garnier E, Herzog F, Lavorel S, Lifran R, Roger-Estrade J, Sarthou JP, Trommetter M (éds) (2008) Agriculture et biodiversité, valoriser les synergies. Expertise scientifique collective. INRA, Paris, $\mathrm{p} 738$

Lechenet M, Dessaint F, Py G et al (2017) Reducing pesticide use while preserving crop productivity and profitability on arable farms. Nat Plants 3:1-6. doi:10.1038/nplants.2017.8

Lemanceau P, Maron P, Mazurier S et al (2015) Understanding and managing soil biodiversity: a major challenge in agroecology. Agron Sustain Dev 35(1):67-81. doi:10.1007/s13593-014-0247-0

Lerman T (2012) A Review of Scholarly Literature on Values-Based Supply Chains. http://www.sarep.ucdavis.edu/sfs/ VBSCLiteratureReview.Lerman.5.31.12_compressed.pdf

Letourneau DK, Armbrecht I, Rivera BS et al (2011) Does plant diversity benefit agroecosystems? A synthetic review. Ecol Appl 21:9-21. doi:10.1890/09-2026.1

Levidow L, Birch K, Papaioannou T (2012) Divergent Paradigms of European Agro-Food Innovation. doi:10.1177/0162243912438143 
Levidow L, Pimbert M, Vanloqueren G (2014) Agroecological research: conforming - or transforming the dominant agro-food regime? Agroecol Sust Food Syst 38:1127-1155

Lieder M, Rashid A (2016) Towards circular economy implementation: a comprehensive review in context of manufacturing industry. J Clean Prod 115:36-51. doi:10.1016/j.jclepro.2015.12.042

Lyon A, Bell MM, Gratton C, Jackson R (2011) Farming without a recipe: Wisconsin graziers and new directions for agricultural science. J Rural Stud 27:384-393. doi:10.1016/j.jrurstud.2011.04.002

Lyson TA, Guptill A (2004) Commodity agriculture, civic agriculture and the future of U.S. farming. Rural Sociol 69:370-385. doi:10.1526/ 0036011041730464

Magrini MB, Anton M, Cholez C, Corre-Hellou G, Duc G, Jeuffroy MH, Meynard JM, Pelzer E, Voisin AS, Walrand S (2016) Why are grainlegumes rarely present in cropping systems despite their environmental and nutritional benefits? Analyzing lock-in in the French agrifood system. Ecol Econ 126:152-162. doi:10.1016/j.ecolecon. 2016.03.024

Marsden T (2010) Mobilizing the regional eco-economy: evolving webs of agri-food and rural development in the UK. Cambridge J Reg Econ Soc 3:225-244. doi:10.1093/cjres/rsq010

Marsden T (2011) From post-productionism to reflexive governance: contested transitions in securing more sustainable food futures. J Rural Stud 29:123-134

Marsden T (2012) Towards a real sustainable agri-food security and food policy: beyond the ecological fallacies? The Political Quarterly 83: 139-145

Marsden T, Farioli F (2015) Natural powers: from the bio-economy to the eco-economy and sustainable place-making. Sustain Sci 10:331344. doi:10.1007/s11625-014-0287-z

Marsden T, Banks J, Bristow G (2000) Food supply chain approaches: exploring their role in rural development. Sociol Ruralis 40:424 438. doi:10.1111/1467-9523.00158

Martin G, Moraine M, Ryschawy J et al (2016) Crop-livestock integration beyond the farm level: a review. Agron Sustain Dev 36:53. doi: 10.1007/s13593-016-0390-x

Mastrangelo ME, Weyland F, Villarino SH, Barral MP, Nahuelhual L, Laterra P (2014) Concepts and methods for landscape multifunctionality and a unifying framework based on ecosystem services. Landsc Ecol 29:345-358

MEA (2005) Millennium ecosystem assessment. Ecosystems and human wellbeing - synthesis. Island Press, Washington

Metereau R, Figuière C (2014) Au carrefour de l'écologie industrielle et du Syal. Premiers jalons pour faire progresser la durabilité d'un développement rural localisé. Développement durable et territoires 5. doi: 10.4000/developpementdurable.10123

Meynard JM, Messéan A, Charlier F, Charrier M, Farès M, Le Bail M, Magrini MB, Savini I (2013) Freins et leviers à la diversification des cultures Etude au niveau des exploitations agricoles et des filières. Synthèse du rapport d'étude, INRA, p 52

Meynard J-M, Jeuffroy M-H, Le Bail M et al (2016) Designing coupled innovations for the sustainability transition of agrifood systems. Agric Syst. doi:10.1016/j.agsy.2016.08.002

Milder JC, Hart AK, Dobie P et al (2014) Integrated landscape initiatives for African agriculture, development, and conservation: a regionwide assessment. World Dev 54:68-80. doi:10.1016/j.worlddev. 2013.07.006

Monteiro CA, Moubarac JC, Cannon G, Ng SW, Popkin B (2013) Ultraprocessed products are becoming dominant in the global food system. Obes Rev 14:21-28. doi:10.1111/obr.12107

Moore KM (2011) Global networks in local agriculture: a framework for negociation. Journal of Agricultural \& Food Information 12:23-39

Moraine M, Duru M, Therond O (2016) A social-ecological framework for analyzing and designing integrated crop-livestock systems from farm to territory levels. Renew Agr Food Syst 1(32):43-56. doi:10. 1017/S1742170515000526
Müller B, Kreuer D (2016) Ecologists should care about insurance, too. Trends Ecol Evol 31:1-2. doi:10.1016/j.tree.2015.10.006

Müller F, Hoffmann-Kroll R, Wiggering H (2000) Indicating ecosystem integrity - theoretical concepts and environmental requirements. Ecol Model 130:13-23

Murdoch J, Marsden T, Banks J (2000) Quality, nature, and embeddedness: some theoretical considerations in the context of the food sector. Econ Geogr 76:107. doi:10.2307/144549

Murgue C, Therond O, Leenhardt D (2015) Toward integrated water and agricultural land management: Participatory design of agricultural landscapes. Land use policy 45:52-63. doi:10.1016/j.landusepol. 2015.01.011

Nassauer JI, Opdam P (2008) Design in science: extending the landscape ecology paradigm. Landsc Ecol 23:633-644

Nicolopoulou-Stamati P, Maipas S, Kotampasi C, Stamatis P, Hens L (2016) Chemical pesticides and human health: the urgent need for a new concept in agriculture. Front Public Health 4:148. doi:10. 3389/fpubh.2016.00148

Nitschelm L, Aubin J, Corson MS, Viaud V, Walter C (2015) Spatial differentiation in life cycle assessment LCA applied to an agricultural territory: current practices and method development. J Clean Prod 112:2472-2484

Noellemeyer E, Six J (2015) Basic principles of soil carbon management for multiple ecosystem benefits. In: Banwart SA, Noellemeyer E, Milne E (eds) Soil carbon: science, management and policy for multiple benefits. SCOPE series 71, pp 265-276

O'Kane G (2012) What is the real cost of our food? Implications for the environment, society and public health nutrition. Public Health Nutr 15:268-276

Park SE, Marshall NA, Jakku E, Dowd AM, Howden SM, Mendham E, Fleming A (2012) Informing adaptation responses to climate change through theories of transformation. Global Envir Chang 22:115-126

Parrott N, Wilson N, Murdoch J (2002) Spatializing quality: regional protection and the alternative geography of food. Eur Urban Reg Stud 9:241-261. doi:10.1177/096977640200900304

Penker M (2006) Mapping and measuring the ecological embeddedness of food supply chains. Geoforum 37:368-379. doi:10.1016/j. geoforum.2005.09.001

Philippot L, Raaijmakers JM, Lemanceau P, van der Putten WH (2013) Going back to the roots: the microbial ecology of the rhizosphere. Nat Rev Microbiol 11:789-799

Pinna S (2016) Alternative food networks, agro-biodiversity and landscape protection: lessons from two rural parks. Reg Stud Reg Sci 3: 456-463. doi:10.1080/21681376.2016.1244488

Pinna S (2017) Alternative farming and collective goals: towards a powerful relationships for future food policies. Land Use Policy 61:339352. doi:10.1016/j.landusepol.2016.11.034

Pisante M, Stagnari F, Acutis M, Bindi M, Brilli L, Stefano VD, Carozzi M (2015) Conservation agriculture and climate change. In: Farroq M, Siddique KM (eds) Conservation agriculture. Springer, Berlin, pp 579-620

Pittelkow CM, Liang X, Linquist BA, van Groenigen KJ, Lee J, Lundy ME, van Gestel N, Six J, Venterea RT, van Kessel C (2015) Productivity limits and potentials of the principles of conservation agriculture. Nature 517:365-368. doi:10.1038/nature13809

Playan E, Mateos L (2006) Modernization and optimization of irrigation systems to increase water productivity. AgricWater Manage 80:100 116

Powles SB, Yu Q (2010) Evolution in action: plants resistant to herbicides. Annu Rev Plant Biol 61:317-347

Pretty J (2008) Agricultural sustainability: concepts, principles and evidence. Philos T R Soc B 363:447-465. doi:10.1098/rstb.2007.2163

Rains GCC, Olson DMM, Lewis WJJ (2011) Redirecting technology to support sustainable farm management practices. Agric Syst 104: $365-370$ 
Rapidel B, Ripoche A, Allinne C et al (2015) Analysis of ecosystem services trade-offs to design agroecosystems with perennial crops. Agron Sustain Dev. doi:10.1007/s13593-015-0317-y

Ratnadass A, Fernandes P, Avelino J, Habib R (2012) Plant species diversity for sustainable management of crop pests and diseases in agroecosystems: a review. Agron Sustain Dev. 32:273-303. doi: 10.1007/s13593-011-0022-4

Reed J, Van Vianen J, Deakin EL et al (2016) Integrated landscape approaches to managing social and environmental issues in the tropics: learning from the past to guide the future. Glob Chang Biol n/a-n/a. doi: $10.1111 / \mathrm{gcb} .13284$

Reeve JR, Hoagland LA, Villalba JJ, Carr PM, Atucha A, Cambardella C, Davis DR, Delate K (2016) Organic farming, soil health, and food quality: considering possible links. Adv Agron 137:319-367. doi: 10.1016/bs.agron.2015.12.003

Renting H, Marsden TK, Banks J (2003) Understanding alternative food networks: exploring the role of short food supply chains in rural development. Environ Plan A 35:393-411. doi:10.1068/a3510

Robledo-Abad C, Althaus HJ, Berndes G et al (2016) Bioenergy production and sustainable development: science base for policymaking remains limited. GCB Bioenergy:1-16. doi:10.1111/gcbb.12338

Rockström J, Steffen W, Noone K, Persson Å, Chapin FS III, Lambin E, Lenton TM, Scheffer M, Folke C, Schellnhuber HJ, Nykvist B, De Wit CA, Hughes T, van der Leeuw S, Rodhe H, Sörlin S, Snyder PK, Costanza R, Svedin U, Falkenmark M, Karlberg L, Corell RW, Fabry VJ, Hansen J, Walker B, Liverman D, Richardson K, Crutzen P, Foley JA (2009a) A safe operating space for humanity. Nature 461:472-475. doi:10.1038/461472a

Rockström J, Steffen W, Noone K, Persson Å, Chapin FS III, Lambin E, Lenton TM, Scheffer M, Folke C, Schellnhuber HJ, Nykvist B, De Wit CA, Hughes T, van der Leeuw S, Rodhe H, Sörlin S, Snyder PK, Costanza R, Svedin U, Falkenmark M, Karlberg L, Corell RW, Fabry VJ, Hansen J, Walker B, Liverman D, Richardson K, Crutzen P, Foley J (2009b) Planetary boundaries: exploring the safe operating space for humanity. Ecol Soc 14:32 http://www. ecologyandsociety.org/vol14/iss2/art32/

Rosmarin A (2004) The Precarious Geopolitics of Phosphorous. Down to Earth: Science and Environment Fortnightly 2004, pp 27-31

Rusch A, Chaplin-Kramer R, Gardiner MM, Hawro V, Holland J, Landis D, Thies C, Tscharntke T, Weisser WW, Winqvist C, Woltz M, Bommarco R (2016) Agricultural landscape simplification reduces natural pest control: a quantitative synthesis. Agric Ecosyst Environ 221:198-204. doi:10.1016/j.agee.2016.01.039

Savary S (2014) The roots of crop health: cropping practices and disease management. Food Secur 6:819-831. doi:10.1007/s12571-0140399-4

Sayer J, Sunderland T, Ghazoul J, Pfund JL, Sheil D, Meijaard E, Ventera M, Boedhihartono AK, Day M, Garcia C, van Oosten C, Buck LE (2013) Ten principles for a landscape approach to reconciling agriculture, conservation, and other competing land uses. P Natl Acad Sci USA 110:8349-8356. doi:10.1073/pnas.1210595110

Schellhorn NA, Gagic V, Bommarco R (2015) Time will tell: resource continuity bolsters ecosystem services. Trends Ecol Evol 30:524 530. doi:10.1016/j.tree.2015.06.007

Scherr SJ, McNeely JA (2008) Biodiversity conservation and agricultural sustainability: towards a new paradigm of "ecoagriculture" landscapes. Philos T R Soc B 363:477-494. doi:10.1098/rstb.2007.2165

Seufert V, Ramankutty N, Foley JA (2012) Comparing the yields of organic and conventional agriculture. Nature 485:229-232. doi:10. 1038/nature 11069

Siegwart M, Graillot B, Blachere Lopez C, Besse S, Bardin M, Nicot PC, Lopez-Ferber M (2015) Resistance to bio-insecticides or how to enhance their sustainability: a review. Front Plant Sci 6:1-19. doi: 10.3389/fpls.2015.00381

Simoncini R (2015) Introducing territorial and historical contexts and critical thresholds in the analysis of conservation of agro- biodiversity by alternative food networks, in Tuscany, Italy. Land Use Policy 42:355-366. doi:10.1016/j.landusepol.2014.08.010

Singh JS, Pandey VC, Singh DPP (2011) Efficient soil microorganisms: a new dimension for sustainable agriculture and environmental development. Agric Ecosyst Environ 140:339-353

Smil V (2000) Phosphorus in the environment: natural flows and human interferences. Annu Rev Energy Environ 25:53-88

Smith P, Martino D, Cai Z et al (2008) Greenhouse gas mitigation in agriculture. Philos Trans R Soc Lond B Biol Sci 363:789-813. doi:10.1098/rstb.2007.2184

Sonnino R, Marsden T (2006) Beyond the divide: rethinking relationships between alternative and conventional food networks in Europe. J Econ Geogr 6:181-199. doi:10.1093/jeg/lbi006

Spiertz J (2010) Nitrogen, sustainable agriculture and food security. A review. Agron Sustain Dev 30:43-55. doi:10.1051/agro:2008064

Spiertz H (2012) Avenues to meet food security. The role of agronomy on solving complexity in food production and resource use. Eur J Agron 43:1-8. doi:10.1016/j.eja.2012.04.004

Stahel WR (2016) The circular economy. Nature 531:435-438. doi:10. $1038 / 531435 \mathrm{a}$

Steingröver EG, Geertsema W, Van Wingerden WKRE (2010) Designing agricultural landscapes for natural pest control: a transdisciplinary approach in the Hoeksche Waard (The Netherlands). Landsc Ecol $25: 825-838$

Stoate C, Boatman ND, Borralho RJ, Carvalho CR, de Snoo GR, Eden P (2001) Ecological impacts of arable intensification in Europe. J Environ Manag 63:337-365. doi:10.1006/jema.2001.0473

Struik PC, Kuyper TW, Brussaard L, Leeuwis C (2014) Deconstructing and unpacking scientific controversies in intensification and sustainability: why the tensions in concepts and values ? Curr Opin Environ Sustain 8:80-88. doi:10.1016/j.cosust.2014.10.002

Šūmane S, Kunda I, Knickel K et al (2017) Local and farmers' knowledge matters! How integrating informal and formal knowledge enhances sustainable and resilient agriculture. J Rural Stud. doi:10. 1016/j.jrurstud.2017.01.020

Tamburini G, De Simone S, Sigura M, Boscutti F, Marini L (2016) Conservation tillage mitigates the negative effect of landscape simplification on biological control. J Appl Ecol (Oerke 2006) 53:233241. doi:10.1111/1365-2664.12544

Tilman D, Fargione J, Wolff B, D'Antonio C, Dobson A, Howarth R, Schindler D, Schlesinger WH, Simberloff D, Swackhamer D (2001) Forecasting agriculturally driven global environmental change. Science 292:281-284

Tilman D, Cassman KG, Matson PA, Naylor R, Polasky S (2002) Agricultural sustainability and intensive production practices. Nature 418:671-677

Timilsena YP, Adhikari R, Casey P, Muster T, Gill H, Adhikari B (2015) Enhanced efficiency fertilisers: a review of formulation and nutrient release patterns. J Sci Food Agr 95:1131-1142. doi:10.1002/jsfa. 6812

Tittonell P, Scopel E, Andrieu N, Posthumus H, Mapfumo P, Corbeels M, van Halsema GE, Lahmar R, Lugandu S, Rakotoarisoa J, Mtambanengwe F, Pound B, Chikowo R, Naudin K, Triomphe B, Mkomwa S (2012) Agroecology-based aggradation-conservation agriculture (ABACO): targeting innovations to combat soil degradation and food insecurity in semi-arid Africa. Field Crop Res 132: 168-174. doi:10.1016/j.fcr.2011.12.011

Tscharntke T, Klein AM, Kruess A, Steffan-Dewenter I, Thies C (2005) Landscape perspectives on agricultural intensification and biodiversity-ecosystem service management. Ecol Lett 8:857-874

Tscharntke T, Tylianakis JM, Rand T, Didham RK, Fahrig L, Batáry P et al (2012) Landscape moderation of biodiversity patterns and processes - eight hypotheses. Biol Rev 87:661-685. doi:10.1111/j. 1469-185X.2011.00216.x

Tzilivakis J, Warner DJ, Green A, Lewis KA, Angileri V (2016) An indicator framework to help maximise potential benefits for 
ecosystem services and biodiversity from ecological focus areas. Ecol Indic 69:859-872. doi:10.1016/j.ecolind.2016.04.045

Umar AS, Iqbal M (2007) Nitrate accumulation in plants, factors affecting the process, and human health implications. A review. Agron Sustain Dev 27:45-57

Vanloqueren G, Baret PV (2009) How agricultural research systems shape a technological regime that develops genetic engineering but locks out agroecological innovations. Res Policy 38:971-983

Verhagen W, Van Teeffelen AJA, Baggio Compagnucci A, Poggio L, Gimona A, Verburg PH (2016) Effects of landscape configuration on mapping ecosystem service capacity: a review of evidence and a case study in Scotland. Landsc Ecol 31:1457-1479. doi:10.1007/ s10980-016-0345-2

Vieweger A, Döring TF (2014) Assessing health in agriculture - towards a common research framework for soils, plants, animals, humans and ecosystems. J Sci Food Agr 95:438-446. doi:10.1002/jsfa.6708

Voinov A, Kolagani N, McCall MK et al (2016) Modelling with stakeholders - Next generation. Environ Model Softw 77:196-220. doi: 10.1016/j.envsoft.2015.11.016

Werling BP, Dickson TL, Isaacs R, Gaines H, Gratton C, Gross KL et al (2014) Perennial grasslands enhance biodiversity and multiple ecosystem services in bioenergy landscapes. Proc Natl Acad Sci U S A 111(4):1652-1657. doi:10.1073/pnas.1309492111

West TO, Marland G (2002) A synthesis of carbon sequestration, carbon emissions, and net carbon flux in agriculture: comparing tillage practices in the United States. Agric Ecosyst Environ 91:217-232. doi:10.1016/S0167-8809(01)00233-X

Wezel A, Soboksa G, McClelland S et al (2015) The blurred boundaries of ecological, sustainable, and agroecological intensification: a review. Agron Sustain Dev. doi:10.1007/s13593-015-0333-y

Wilson G (2008) From "weak" to "strong" multifunctionality: conceptualising farm-level multifunctional transitional pathways. J Rural Stud 24:367-383. doi:10.1016/j.jrurstud.2007.12.010

Wilson C, Tisdell C (2001) Why farmers continue to use pesticides despite environmental, health and sustainability costs. Ecol Econ 39: $449-462$

Wu J (2013) Landscape sustainability science: ecosystem services and human well-being in changing landscapes. Landsc Ecol 28:999-1023

Zhang W, Ricketts TH, Kremen C, Carney K, Swinton SM (2007) Ecosystem services and dis-services to agriculture. Ecol Econ 64: 253-260 